\title{
Clinical significance of metabolism-related biomarkers in non-Hodgkin lymphoma - MCT1 as potential target in diffuse large B cell lymphoma
}

\author{
Julieta Afonso ${ }^{1,2}$ - Tatiana Pinto ${ }^{1,2}$ • Susana Simões-Sousa ${ }^{1,2,3}$ • Fernando Schmitt ${ }^{4}$ - Adhemar Longatto-Filho ${ }^{1,2,5,6}$. \\ Céline Pinheiro $^{1,2,6,7} \cdot$ Herlander Marques ${ }^{1,2,8,9} \cdot$ Fátima Baltazar $^{1,2}$
}

Accepted: 4 February 2019 / Published online: 21 February 2019

(C) International Society for Cellular Oncology 2019

\begin{abstract}
Purpose Increased glycolytic activity with accumulation of extracellular lactate is regarded as a hallmark of cancer. In lymphomas, FDG-PET has undeniable diagnostic and prognostic value, corroborating that these tumours are avid for glucose. However, the role of glycolytic metabolism-related molecules in lymphoma is not well known. Here, we aimed to evaluate the clinical and prognostic significance of a panel of glycolytic metabolism-related molecules in primary non-Hodgkin lymphomas (NHL) and to test in vitro the putative therapeutic impact of lactate transport inhibition.

Methods We assessed, by immunohistochemistry, the expression of the metabolism-related molecules MCT1, MCT2, MCT4, CD147, GLUT1, LDHA and CAIX in both tumour and stroma compartments of tissue sections obtained from 104 NHL patients. In addition, the lymphoma-derived cell lines $\mathrm{OZ}$ and DOHH-2 were used to evaluate the effect of AZD3965 on their viability and on apoptosis induction, as well as on extracellular lactate accumulation.

Results We found that expression of MCT1 in the NHL tumour compartment was significantly associated with a poor clinicopathological profile. We also found that MCT4 and CAIX were present in the stromal compartment and correlated with an aggressive phenotype, while MCT1 was absent in this compartment. In addition, we found that AZD3965-mediated disruption of MCT1 activity led to inhibited NHL cell viability and extracellular lactate accumulation, while increasing apoptotic cell death. Conclusions Our results indicate that elevated glycolytic activity is associated with NHL aggressiveness, pointing at metabolic cooperation, mediated by MCT1 and MCT4, between tumour cells and their surrounding stroma. MCT1 may serve as a target to treat NHL (diffuse large B cell lymphoma) patients with high MCT1/low MCT4 expressing tumours. Further (pre-)clinical studies are required to allow the design of novel therapeutic strategies aimed at e.g. reprogramming the tumour microenvironment.
\end{abstract}

Keywords Non-Hodgkin lymphoma $\cdot$ Diffuse large B cell lymphoma $\cdot$ Warburg effect $\cdot$ Monocarboxylate transporters $\cdot$ Metabolic symbiosis $\cdot$ AZD3965

Electronic supplementary material The online version of this article (https://doi.org/10.1007/s13402-019-00426-2) contains supplementary material, which is available to authorized users.

Fátima Baltazar

fbaltazar@med.uminho.pt

1 Life and Health Sciences Research Institute (ICVS), School of Medicine, University of Minho, Campus de Gualtar, 4710-057 Braga, Portugal

2 ICVS/3B's - PT Government Associate Laboratory, Braga/ Guimarães, Portugal

3 Division of Cancer Biology, The Institute of Cancer Research, London, UK

4 Institute of Molecular Pathology and Immunology (IPATIMUP) and Medical Faculty, University of Porto, Porto, Portugal
5 Laboratory of Medical Investigation (LIM 14), Faculty of Medicine, São Paulo State University, São Paulo, Brazil

6 Molecular Oncology Research Center, Barretos Cancer Hospital, São Paulo, Brazil

7 Barretos School of Health Sciences Dr. Paulo Prata - FACISB, São Paulo, Brazil

Department of Oncology, Hospital de Braga, Braga, Portugal

9 CINTESIS, Center for Health Technology and Services Research, Faculty of Medicine, University of Porto, Porto, Portugal 


\section{Introduction}

Non-Hodgkin lymphomas (NHLs), the main representatives (90\%) of lymphomas, encompass a heterogeneous group of lymphoproliferative neoplasms that may arise from B- $(80$ $90 \%$ of the cases), T- or NK cells at various stages of differentiation [1]. In several types of B cell lymphoma the genetic basis involves the immunoglobulin heavy chain $(\operatorname{IgH})$ gene fused to different partner genes, whereas Epstein virus infection and/or immunodeficiency may also play a role [2]. According to the latest GLOBOCAN data $\sim 386,000$ new cases were diagnosed in 2012 worldwide, representing $2.7 \%$ of all cancers, with a mortality burden of $52 \%$ [3]. NHLs typically arise in lymphoid tissues (lymph nodes, spleen or bone marrow), although they can develop in any tissue [1]. The 2016 World Health Organization (WHO) classification of Lymphoid Neoplasms distinguishes over 80 different types of NHLs, based on combined morphological, immunophenotypical, clinical, genetic and aetiological data. The most common types are the relatively aggressive diffuse large B cell lymphoma (DLBCL) and the relatively indolent follicular lymphoma (FL), representing $\sim 35$ and $\sim 20 \%$ of all NHLs, respectively [4]. The Ann Arbor classification system is widely used for disease staging, and the International Prognostic Index (IPI) is the preferred prognostic model for NHL patients $[5,6]$. While providing diagnostic and prognostic information, these tools are usually complemented by other ancillary methods to allow the early identification of patients with immuno-chemotherapy refractory disease. Positron emission tomography with 2-[18F]fluoro-2-deoxy-D-glucose (FDG-PET) is a reliable cancer outcome predictor $[7,8]$ based on the prevalence of enhanced glucose uptake by human cancers. FDG-PET is increasingly used for the global assessment of lymphomas, allowing not only evaluation of tumour extensiveness and aggressiveness, but also quantification of their metabolic activity [9-12]. CHOP-R (a combination chemotherapy containing cyclophosphamide, doxorubicin, vincristine, prednisolone and rituximab) is currently the standard first line therapy for NHL patients [13]. However, almost half of the treated DLBCL patients, and eventually all low grade NHL patients, will develop recurrence and/ or disease progression. Based on a better understanding of the biology underlying lymphoma development, the management of aggressive disease is currently being fine-tuned through molecular-driven approaches complying with precision medicine guidelines [1].

Cancer is nowadays not only viewed as a complex genetic disease, but also as a disease with heterogeneous bioenergetic metabolic features, and in which elevated glycolytic rates are preponderant $[14,15]$. Metabolic reprogramming postulates that tumour cells avidly consume glucose via upregulated glucose transporters (GLUT) and glycolytic enzymes, and produce large amounts of lactate even under aerobic conditions. To ensure intracellular $\mathrm{pH}$ homeostasis, $\mathrm{pH}$ regulators such as the hypoxia-inducible carbonic anhydrase IX (CAIX) and the lactate-extruders monocarboxylate transporters (MCT) are also upregulated, which further contributes to the acidification of the tumour microenvironment. This microenvironmental acidosis sculpts an acid-resistant phenotype that supports and favours malignancy, i.e., the migration and invasion of cancer cells $[15$, 16]. In addition, metabolic synergism among cancer cells, and between cancer and stromal cells ("reverse Warburg effect") have been described MCT transfers lactate from one cell type to another ("lactate shuttle"), which is utilized for energy production, proliferation and chemoresistance [17]. Potential metabolic vulnerabilities are currently being therapeutically explored in preclinical and clinical settings, with several molecular targets showing promising anticancer effects $[15,18]$.

Despite the use of FDG-PET as an ancillary diagnostic and prognostic approach for lymphomas, little is known about the preponderance of metabolic reprogramming of their microenvironment. Using a Burkitt's lymphoma model, Kim et al. observed enhanced expression of key regulators of glucose metabolism such as hexokinase 2 (HK2) and pyruvate dehydrogenase kinase 1 (PDH1) [19]. Another in vitro study revealed that reduction of lactate dehydrogenase A (LDHA) leads to decreased ATP levels and increased oxidative stress and cell death [20]. Modulation of glucose metabolism through glycolysis-targeting drugs in animal lymphoma models has yielded promising effects with respect to decreasing tumour volumes, increasing survival and promoting chemosensitization [20-23]. Importantly, it was found that these treatments inhibited MCT1 expression [22, 23]. Disruption of MCT1 has been found to lead to intracellular lactate accumulation and, consequently, decreased glycolysis and increased cell death, which could be further potentiated by metformin treatment [24].

In order to elucidate the role of glycolytic metabolism-related molecules, i.e., MCT1, MCT2, MCT4, CD147, GLUT1, LDHA and CAIX, in NHLs, we assessed their expression and evaluated their impact on clinicopathological and survival parameters in a comprehensive cohort of 104 patients diagnosed with high or low grade NHL. In addition, we assessed the therapeutic impact of lactate transport inhibition in DLBCL-derived cell lines using the MCT1 inhibitor AZD3965.

\section{Materials and methods}

\subsection{Patients and tissue samples}

A total of 104 patients diagnosed from June 1998 to December 2011 with NHL at Braga or Guimarães Hospital were enrolled in this study. Clinical and/or follow-up data were collected from the patients or their clinical records. Prior approval was obtained from both Ethics Committees of the involved institutions. Only patients with a diagnosis of 
indolent or aggressive NHL, aged over 18 years, and for whom adequate tumour samples were available for analysis, where included. Representative formalin-fixed paraffin-embedded excisional biopsy specimens were obtained from all patients included. The median age of the patients was 67 years (range: 19-97 years). Sixty-four patients (61.5\%) were aged over 60 . Fifty-four patients $(51.9 \%)$ were male and fifty (48.1\%) were female.

Haematoxylin-eosin stained sections were reviewed according to standard histopathological examination by two independent haematopathologists. The lymphomas were classified according to the World Health Organization (WHO) classification of tumours of haematopoietic and lymphoid tissues [25] and the Ann Arbor classification system (with modifications introduced at the Cotswolds meeting for Hodgkin lymphoma) [26].

For statistical analysis the lesions were divided into two groups, based on histological aggressiveness, as high grade NHL (corresponding to DLBCL) and low grade NHL (corresponding to the indolent subtypes of FL, mantle cell and marginal zone lymphomas, and a small number of lymphoplasmacytic, lymphocytic and unclassified differentiated lymphomas, grouped as "other, low grade"). Mantle cell lymphomas are difficult to assign to high or low grade groups, because their histological variants may differ widely in clinical behaviour and proliferative rate [27]. Since the classical variant, representing $88 \%$ of their total number, has a low proliferative rate (despite a usually dismal clinical behaviour), these cases were included here in the low grade group.

IPI (International Prognostic Index) [28] and FLIPI (Follicular Lymphoma International Prognostic Index) [29] were used to determine the prognosis of patients with high and low grade tumours, respectively. The patient's performance status was determined using the ECOG (Eastern Cooperative Oncology Group) scale [30]. The clinicopathological data are listed in Table 1.

Following diagnosis, $86(82.7 \%)$ of the patients underwent immuno-chemotherapy. Surgical procedures were performed to obtain histological samples for diagnosis. Twelve (11.6\%) patients received radiotherapy for consolidation of PETpositive residual masses. Cases for whom diagnosis and initial evaluation were obtained from 1998 to 2007 were reviewed according to the response criteria of the International Working Group (IWG) published in 1999 [31]. The remaining cases were reviewed according to the new IWG criteria published in 2007 [32]. For statistical analysis, these guidelines were harmonized, considering complete response unconfirmed $(\mathrm{CRu})$ as complete response (CR). The recommendations of IWG were also adopted for PET interpretation through visual assessment. Based on these criteria, $51(59.3 \%)$ of the treated patients achieved a complete remission and $25(29.1 \%)$ a partial remission, whereas $10(11.6 \%)$ patients did not respond to the treatment. The mean and median follow-up times were 51.9 and 53.3 months (range: 1-204 months), respectively.
Table 1 Clinicopathological parameters

\begin{tabular}{|c|c|}
\hline \multirow[t]{2}{*}{ Gender } & Male \\
\hline & Female \\
\hline \multirow[t]{2}{*}{ Age } & $\leq 60$ years \\
\hline & $>60$ years \\
\hline \multirow[t]{2}{*}{ Pathological stage (Ann Arbor) } & $\mathrm{I} / \mathrm{II}$ \\
\hline & III/IV \\
\hline \multirow[t]{2}{*}{ Grade } & Low (indolent) \\
\hline & High (aggressive) \\
\hline \multirow[t]{5}{*}{ Subtype of NHL } & Follicular \\
\hline & Mantle cell \\
\hline & Marginal zone \\
\hline & Others, low grade \\
\hline & Diffuse large B-cell \\
\hline \multirow[t]{2}{*}{ Extranodal involvement } & Yes \\
\hline & No \\
\hline \multirow[t]{3}{*}{ FLIPI (low grade tumours) } & Low $(0-1)$ \\
\hline & Intermediate (2) \\
\hline & High (3-4-5) \\
\hline \multirow[t]{3}{*}{ IPI (high grade tumours) } & Low $(0-1)$ \\
\hline & Intermediate $(2-3)$ \\
\hline & High (4-5) \\
\hline \multirow[t]{2}{*}{ B symptoms ${ }^{\text {a }}$} & No \\
\hline & Yes \\
\hline \multirow[t]{3}{*}{ LDH serum levels ${ }^{b}$} & Normal \\
\hline & High \\
\hline & Unknown \\
\hline \multirow[t]{3}{*}{$\beta 2$-microglobulin serum levels ${ }^{c}$} & Normal \\
\hline & High \\
\hline & Unknown \\
\hline \multirow[t]{3}{*}{ Albumin serum levels ${ }^{\mathrm{d}}$} & Normal \\
\hline & Low \\
\hline & Unknown \\
\hline \multirow[t]{3}{*}{ Hemoglobin serum levels ${ }^{\mathrm{e}}$} & Normal \\
\hline & Low \\
\hline & Unknown \\
\hline \multirow[t]{2}{*}{ ECOG performance status } & $0-1$ \\
\hline & $\geq 2$ \\
\hline \multirow[t]{3}{*}{ First treatment results } & Complete response \\
\hline & Partial response \\
\hline & No response \\
\hline
\end{tabular}

${ }^{\mathrm{a}}$ Includes fever $>38^{\circ} \mathrm{C}$, night sweats, and unintentional weight loss of $>10 \% ;{ }^{\mathrm{b}}$ cut-off of $480 \mathrm{UI} / 1 ;{ }^{\mathrm{c}}$ cut-off of $3.0 \mathrm{mg} / \mathrm{l} ;{ }^{\mathrm{d}}$ cut-off of $3.0 \mathrm{~g} / \mathrm{dl} ;{ }^{\mathrm{e}}$ cut-off of $12 \mathrm{~g} / \mathrm{dl}$

The corresponding follow-up times for high grade NHL patients were 41.8 and 47.1 months (range: $1-141$ months), respectively, and for low grade NHL patients 63.1 and 58.9 months (range: 1-204 months), respectively. Progression occurred in 22 of the $35(62.9 \%)$ patients that had achieved a partial remission or did not respond to the first 
treatment. Progression-free survival (PFS) was defined as the time from the first treatment until recurrence, progression or death from any cause. Overall survival (OS) was defined as the time from the first treatment until death from any cause.

\subsection{Immunohistochemistry and evaluation}

After selection of representative tumour areas in haematoxylineosin stained sections ( $4 \mu \mathrm{m}$-thick), the lymphoma samples were organized into six tissue microarrays (TMAs). To obtain representative sampling and to avoid sample loss, the sections were duplicated in the TMAs. Immunohistochemistry using the streptavidin-biotin-peroxidase complex technique (Ultravision Detection System Anti-polyvalent, HRP, Lab Vision Corporation) was used for MCT2, MCT4, GLUT1, LDHA and CAIX detection, and the avidin-biotin-peroxidase complex assay (VECTASTAIN Elite ABC Reagent, RTU, Vector Laboratories, Inc.) was used for MCT1 and CD147 detection, as previously reported [33]. The primary antibodies, as well as the dilutions used, are listed in Table 2. The incubations were performed at room temperature (RT) during $1 \mathrm{~h}$ (MCT2, MCT4, GLUT1, LDHA and CAIX) or overnight (ON) (MCT1 and CD147). Negative controls were included by omitting the primary antibodies. Colon carcinoma sections were used as positive controls for MCT1, MCT4, CD147 and LDHA detection, whereas for MCT2, GLUT1 and CAIX detection normal kidney, head and neck cancer and gastric carcinoma sections were used, respectively.

Immunostained tissue sections were evaluated by light microscopy for MCT1, MCT2, MCT4, CD147, GLUT1, LDHA and CAIX cytoplasmic, nuclear and/or plasma membrane staining of the tumour cells. The cancer-associated stroma (mainly composed of fibroblasts and connective tissue) was also assessed for immunoexpression of the biomarkers. Regarding the tumour cells, a semi-quantitative system was used to grade the immunohistochemistry results, considering the percentage of immunoreactive cells (score $0,0 \%$ positive cells; score $1,<5 \%$ positive cells; score $2,5-50 \%$ positive cells; score $3,>50 \%$ positive cells) and the intensity of staining (score 0 , negative; score 1, weak; score 2, intermediate; score 3 , strong). Final scores $\geq 3$ were considered positive for all the biomarkers studied, as reported before [33].

\subsection{Cell lines and culture procedures}

In the present study, two DLBCL-derived cell lines with a $\mathrm{t}(14 ; 18)(\mathrm{q} 32 ; \mathrm{q} 21)$ translocation were used: OZ (CVCL_M710) and DOHH-2 (ACC 47, DSMZ). Both cell lines were cultured in suspension in RPMI-1640 medium supplemented with GlutaMAX ${ }^{\mathrm{TM}}\left(\mathrm{Gibco}^{\mathrm{TM}}\right), 10 \%$ heat inactivated foetal bovine serum (FBS, $\mathrm{Gibco}^{\mathrm{TM}}$ ) and antibiotics $\left(1 \%\right.$ penicillin/streptomycin solution, $\left.\mathrm{Gibco}^{\mathrm{TM}}\right)$. The cells were incubated in a humidified atmosphere at $37{ }^{\circ} \mathrm{C}$ and $5 \% \mathrm{CO}_{2}$ and were passaged every $2-3$ days.

\subsection{Reagents}

The antibodies and dilutions used for immunohistochemistry, immunofluorescence and Western blotting are listed in Table 2. For in vitro treatment, cells were incubated with $0.01 \%$ DMSO vehicle control or with the MCT1 inhibitor AZD3965 (Cayman Chemical) at the indicated concentrations and time points.
Table 2 Primary antibodies and dilutions used for immunohistochemistry (IHC), immunofluorescence (IFC) and Western blotting (WB)

\begin{tabular}{lllll}
\hline Antibody against & Reference (Company) & IHC dilution & IFC dilution & WB dilution \\
\hline MCT1 & AB3538P (Chemicon®) & $1: 200$ & $1: 200$ & - \\
& sc-365501 (Santa Cruz Biotechnology®) & - & - & $1: 500$ \\
MCT2 & sc-50322 (Santa Cruz Biotechnology®) & $1: 200$ & - & - \\
& sc-166925 (Santa Cruz Biotechnology®) & - & $1: 100$ & $1: 200$ \\
MCT4 & sc-50329 (Santa Cruz Biotechnology®) & $1: 500$ & $1: 500$ & $1: 500$ \\
CD147 & 18-7344 (Zymed® Laboratories) & $1: 500$ & - & - \\
& sc-71,038 (Santa Cruz Biotechnology®) & - & $1: 500$ & $1: 500$ \\
GLUT1 & ab15309 (AbCam) & $1: 500$ & $1: 500$ & $1: 500$ \\
LDHA & ab101562 (AbCam) & $1: 1000$ & - & - \\
& sc-100775 (Santa Cruz Biotechnology®) & - & $1: 200$ & $1: 1000$ \\
CAIX & ab15086 (AbCam) & $1: 2000$ & $1: 2000$ & $1: 2000$ \\
PARP & \#9542 (Cell Signalling® Technology) & - & - & $1: 500$ \\
Bcl-xL & sc-8392 (Santa Cruz Biotechnology®) & - & - & $1: 300$ \\
Bim & \#2933 (Cell Signalling® Technology) & - & - & $1: 1000$ \\
Bax & sc-7480 (Santa Cruz Biotechnology®) & - & - & $1: 500$ \\
Caspase 9 & $\# 9508$ (Cell Signalling® Technology) & - & - & $1: 500$ \\
\hline
\end{tabular}




\subsection{Immunofluorescence}

Suitable amounts of $\mathrm{OZ}$ and DOHH-2 cell suspensions were pipetted into cytofunnels and centrifuged in a Cytospin (Shandon ${ }^{\mathrm{TM}}$ ) at $1000 \mathrm{rpm}$ for $5 \mathrm{~min}$, using medium acceleration. Cells attached to the cytoslides were fixed and permeabilized with cold methanol for 20 min and, subsequently, blocked with $5 \%$ BSA for $30 \mathrm{~min}$. Incubation with primary antibodies (Table 2) was performed at $4{ }^{\circ} \mathrm{C}$, ON. After subsequent incubation with fluorescence-conjugated secondary antibodies [goat anti-rabbit-Alexa Fluor 488 (1:500, A11008, Invitrogen $\left.^{\mathrm{TM}}\right)$ and goat anti-mouse-Alexa Fluor 594 (1:500, A11032, Invitrogen $\left.{ }^{\mathrm{TM}}\right)$ ] for $1 \mathrm{~h}$ at RT, the cells were mounted in Vectashield ${ }^{\circledR}$ Mounting Media with 4',6-diamidino-2phenylindole (DAPI) (Vector Laboratories, Inc.). Finally, images were obtained under a fluorescence microscope (Olympus® IX81).

\subsection{Western blotting}

Cells that were routinely sub-cultured in T25 flasks at a density of $1 \times 10^{6}$ cells $/ \mathrm{ml}$, or cells seeded in 6-well plates $(2 \times$ $10^{6}$ cells/well) and treated with $0.01 \%$ DMSO, 10,100 or $1000 \mathrm{nM}$ AZD3965 for $72 \mathrm{~h}$, were collected and disrupted in cold lysis buffer (supplemented with protease inhibitors) for $10 \mathrm{~min}$. Next, cell lysates were collected after centrifugation at $13,000 \mathrm{rpm}, 15 \mathrm{~min}$ at $4{ }^{\circ} \mathrm{C}$ and protein quantification was performed using the Bradford assay (Sigma-Aldrich $®$ ). Equal amounts $(20 \mu \mathrm{g})$ of total protein were separated on $12 \%$ polyacrylamide gels by SDS-PAGE (100 V for $90 \mathrm{~min}$ ) and transferred to nitrocellulose membranes using a Trans-Blot ${ }^{\circledR}$ Turbo $^{\mathrm{TM}}$ Transfer system ( $25 \mathrm{~V}$ for $\left.30 \mathrm{~min}\right)$. The resulting blots were incubated $\mathrm{ON}$ at $4{ }^{\circ} \mathrm{C}$ with specific primary antibodies (Table 2) and, subsequently, incubated for $1 \mathrm{~h}$ at RT with specific secondary antibodies [m-IgGk BP-HRP (1:2500 dilution, sc-516,102, Santa Cruz Biotechnology®) or mouse anti-rabbit IgG-HRP (1:2599 dilution, sc-2357, Santa Cruz Biotechnology $($ ]. Actin (C-2, 1:500 dilution, sc-8432, Santa Cruz Biotechnology $\left.{ }^{\circledR}\right)$ or $\alpha$-Tubulin (1:2500 dilution, ab15246, AbCam) were used as loading controls. Finally, the blots were developed using enhanced chemiluminescence (Supersignal West Femto kit, Pierce ${ }^{\mathrm{TM}}$ ) on a Chemidoc ${ }^{\mathrm{TM}}$ XRS+ system (Bio-rad).

\subsection{Cellular viability assays and extracellular lactate measurements}

Cells were seeded in 48-well plates at a density of $2.5 \times 10^{5}$ cells/well, and treated with either vehicle control or 10, 100 or $1000 \mathrm{nM}$ AZD1365 for 24, 48 and $72 \mathrm{~h}$. Cell viability following 24, 48 and $72 \mathrm{~h}$ incubation was determined using a CellTiter 96 Aqueous One Solution Cell Proliferation assay (MTS, Promega) and a Trypan blue exclusion assay to quantify death cells, respectively. Extracellular lactate content was measured after 24,48 and $72 \mathrm{~h}$ incubation using a commercial enzymatic colorimetric kit (Spinreact).

\subsection{Statistical analysis}

Immunohistochemistry data were analysed using the Statistical Package for Social Sciences (SPSS) software for Windows, version 25. Statistical significance of associations between biomarker immunoexpression and clinicopathological/prognostic parameters was evaluated using Pearson's chi-square $\left(\chi^{2}\right)$ and Fisher's exact tests. Kaplan-Meier curves were used to assess PFS and OS rates using Log-Rank or Breslow tests. $P$ values $<0.05$ were considered significant. Multivariate analysis using Cox proportional hazards analysis was performed with parameters that reached statistical significance in the univariate analyses. The in vitro data were analysed using GraphPad Prism 6 software, with the Student's t test, considering significance when $p<0.05$.

\section{Results}

\subsection{Prognostic significance of clinicopathological parameters}

We found that the NHL patient survival rates were significantly influenced by clinicopathological variables: lower 5-year PFS and OS rates were observed in patients portending parameters of tumour aggressiveness, i.e., stage III/IV $(p=0.002$ and $p=0.035)$, high grade $(p=0.022$ and $p=0.029)$, diffuse large B cell type of NHL ( $p=0.005$ and $p=0.006)$, elevated LDH serum levels $(p<0.001)$, an ECOG performance status of two or more scale points $(p<0.001)$ and no response to the first treatment $(p<0.001)$. Detailed data are listed in Table 3. The prognostic significance of the clinicopathological parameters was also analysed separately for high grade and low grade NHL patients. These results are shown in the Supplementary data.

\subsection{Immunoexpression of biological parameters in primary lymphoma tissues}

Immunostaining was found to be positive for MCT1 (Fig. 1a), MCT2 (Fig. 1c) and MCT4 (Fig. 1d) in 24.3\%, 17.5\% and $34.8 \%$ of the NHL cases (tumour compartment), respectively. Membrane positivity was present in all of these cases. Cytoplasmic expression was not considered as an isolated entity, since cytoplasm and membrane could hardly be distinguished in the vast majority of the malignant lymphocytes due to their preponderant nuclei. MCT1 nuclear expression (Fig. 1b) was observed in tumour cells of six NHL cases. Regarding the stromal compartment, positive reactions for MCT2 (Fig. 
Table 3 Associations between clinicopathological parameters and outcome rates (5-year progression-free survival, PFS, and 5-year overall survival, OS)

\begin{tabular}{|c|c|c|c|c|c|c|}
\hline & & $\mathrm{n}$ & 5-year PFS rate, $\%$ & $p^{\mathrm{f}}$ & 5 -year OS rate, $\%$ & $p^{\mathrm{f}}$ \\
\hline Gender & $\begin{array}{l}\text { Male } \\
\text { Female }\end{array}$ & $\begin{array}{l}54 \\
50\end{array}$ & $\begin{array}{l}54.3 \\
59.4\end{array}$ & ns & $\begin{array}{l}53.9 \\
68.4\end{array}$ & ns \\
\hline Age & $\begin{array}{l}\leq 60 \text { years } \\
>60 \text { years }\end{array}$ & $\begin{array}{l}40 \\
64\end{array}$ & $\begin{array}{l}66.8 \\
50.3\end{array}$ & 0.037 & $\begin{array}{l}79.7 \\
49.9\end{array}$ & 0.004 \\
\hline Pathological stage & $\begin{array}{l}\mathrm{I} / \mathrm{II} \\
\mathrm{III} / \mathrm{IV}\end{array}$ & $\begin{array}{l}46 \\
58\end{array}$ & $\begin{array}{l}77.8 \\
40.1\end{array}$ & 0.002 & $\begin{array}{l}76.9 \\
49.9\end{array}$ & 0.035 \\
\hline Grade & $\begin{array}{l}\text { Low } \\
\text { High }\end{array}$ & $\begin{array}{l}49 \\
55\end{array}$ & $\begin{array}{l}64.3 \\
50.0\end{array}$ & 0.022 & $\begin{array}{l}70.5 \\
54.7\end{array}$ & 0.029 \\
\hline \multirow[t]{4}{*}{ Subtype of NHL } & $\begin{array}{l}\text { Follicular } \\
\text { Mantle cell }\end{array}$ & $\begin{array}{l}24 \\
6\end{array}$ & $\begin{array}{l}80.7 \\
16.7\end{array}$ & 0.005 & $\begin{array}{l}70.9 \\
33.3\end{array}$ & 0.006 \\
\hline & Marginal zone & 12 & 75.0 & & 91.7 & \\
\hline & Others, low grade & 7 & 26.8 & & 26.8 & \\
\hline & Diffuse large B-cell & 55 & 50.0 & & 54.7 & \\
\hline Extranodal involvement & $\begin{array}{l}\text { Yes } \\
\text { No }\end{array}$ & $\begin{array}{l}30 \\
74\end{array}$ & $\begin{array}{l}68.3 \\
52.3\end{array}$ & ns & $\begin{array}{l}82.7 \\
53.7\end{array}$ & 0.068 \\
\hline \multirow[t]{2}{*}{ FLIPI (low grade tumours) } & $\begin{array}{l}\text { Low } \\
\text { Intermediate }\end{array}$ & $\begin{array}{l}17 \\
17\end{array}$ & $\begin{array}{l}85.9 \\
64.7\end{array}$ & 0.014 & $\begin{array}{l}92.3 \\
63.5\end{array}$ & 0.008 \\
\hline & High & 15 & 33.3 & & 35.2 & \\
\hline \multirow[t]{2}{*}{ IPI (high grade tumours) } & $\begin{array}{l}\text { Low } \\
\text { Intermediate }\end{array}$ & $\begin{array}{l}22 \\
30\end{array}$ & $\begin{array}{l}76.6 \\
35.6\end{array}$ & $<0.001$ & $\begin{array}{l}81.3 \\
40.2\end{array}$ & $<0.001$ \\
\hline & High & 3 & 0.0 & & 0.0 & \\
\hline B symptoms ${ }^{\text {a }}$ & $\begin{array}{l}\text { No } \\
\text { Yes }\end{array}$ & $\begin{array}{l}70 \\
34\end{array}$ & $\begin{array}{l}63.5 \\
43.7\end{array}$ & 0.014 & $\begin{array}{l}71.1 \\
44.0\end{array}$ & 0.006 \\
\hline LDH serum levels ${ }^{b}$ & $\begin{array}{l}\text { Normal } \\
\text { High }\end{array}$ & $\begin{array}{l}72 \\
29\end{array}$ & $\begin{array}{l}66.9 \\
32.5\end{array}$ & $<0.001$ & $\begin{array}{l}70.8 \\
36.6\end{array}$ & $<0.001$ \\
\hline$\beta 2$-microglobulin serum levels ${ }^{c}$ & $\begin{array}{l}\text { Normal } \\
\text { High }\end{array}$ & $\begin{array}{l}53 \\
22\end{array}$ & $\begin{array}{l}64.6 \\
51.0\end{array}$ & ns & $\begin{array}{l}67.5 \\
53.7\end{array}$ & 0.049 \\
\hline Albumin serum levels ${ }^{\mathrm{d}}$ & $\begin{array}{l}\text { Normal } \\
\text { Low }\end{array}$ & $\begin{array}{l}87 \\
11\end{array}$ & $\begin{array}{l}61.1 \\
22.7\end{array}$ & $<0.001$ & $\begin{array}{l}66.5 \\
27.3\end{array}$ & 0.001 \\
\hline Hemoglobin serum levels ${ }^{e}$ & $\begin{array}{l}\text { Normal } \\
\text { Low }\end{array}$ & $\begin{array}{l}63 \\
40\end{array}$ & $\begin{array}{l}69.5 \\
38.9\end{array}$ & $<0.001$ & $\begin{array}{l}76.1 \\
42.0\end{array}$ & $<0.001$ \\
\hline ECOG performance status & $\begin{array}{l}0-1 \\
\geq 2\end{array}$ & $\begin{array}{l}92 \\
12\end{array}$ & $\begin{array}{l}61.0 \\
25.0\end{array}$ & $<0.001$ & $\begin{array}{l}67.2 \\
25.0\end{array}$ & $<0.001$ \\
\hline \multirow[t]{2}{*}{ First treatment results } & $\begin{array}{l}\text { Complete response } \\
\text { Partial response }\end{array}$ & $\begin{array}{l}51 \\
25\end{array}$ & $\begin{array}{l}77.3 \\
44.5\end{array}$ & $<0.001$ & $\begin{array}{l}83.3 \\
44.2\end{array}$ & $<0.001$ \\
\hline & No response & 10 & 20.0 & & 30.0 & \\
\hline
\end{tabular}

${ }^{\mathrm{a}}$ Includes fever $>38{ }^{\circ} \mathrm{C}$, night sweats, and unintentional weight loss of $>10 \% ;{ }^{\mathrm{b}}$ cut-off of $480 \mathrm{UI} /{ }{ }^{\mathrm{c}}$ cut-off of $3.0 \mathrm{mg} / \mathrm{l} ;{ }^{\mathrm{d}}$ cut-off of $3.0 \mathrm{~g} / \mathrm{dl} ;{ }^{\mathrm{e}}$ cut-off of $12 \mathrm{~g} / \mathrm{dl} ;{ }^{\mathrm{f}}$ Log-Rank or Breslow tests

1c) and MCT4 (Fig. 1e) were observed in $8.7 \%$ and $10.9 \%$ of the cases, respectively. CD147 expression was considered negative in all cases, both in the tumour and stroma compartments (Table 4) [normal kidney tissues present in the TMAs were positive (Fig. 1f), as well as the colon carcinoma tissues (positive controls)]. GLUT1 (Fig. 1g) and CAIX (Fig. 1h) plasma membrane positivity was observed in $13.8 \%$ and $70.8 \%$ of the NHL tumour tissue sections, respectively. CAIX expression was also observed in the stromal compartments (Fig. 1h) in $10.4 \%$ of the cases. Regarding LDHA (Fig. 1i), only $5.6 \%$ of the cases were positively graded (cytoplasmic staining) (Table 3).

\subsection{Clinicopathological and prognostic significance of biological parameters}

Next, associations between the clinicopathological variables and the biological parameters were assessed (except for CD147, due to uniform negativity in both tumour and stromal compartments) (Table 3). A separate analysis for high and low grade NHL cases was performed, but through this analysis no statistically significant associations were noted (data not shown). Analysis of the complete cohort of NHL samples $(n=104)$ revealed that MCT1 and MCT4 tumour immunoexpression (membrane staining) was associated with high grade $(p=0.039$ and $p=0.051$, 
Fig. 1 MCT1 (a and b), MCT2 (c), MCT4 (d and e), CD147 (f), GLUT1 (g), CAIX (h) and LDHA (i) immunoexpression (cytoplasm and/or plasma membrane staining) in tissue sections of non-Hodgkin lymphoma patients. In $\mathrm{b}$, nuclear MCT1 staining is present in the tumour compartment. In c, e and $\mathrm{h}$, positive staining for MCT2, MCT4 and CAIX (respectively) is present in the tumour stroma. In $\mathrm{F}$, negative CD147 expression is shown together with the adjacent positive internal control (inset). Original magnification $200 \mathrm{x}$ (except for b, 400x)
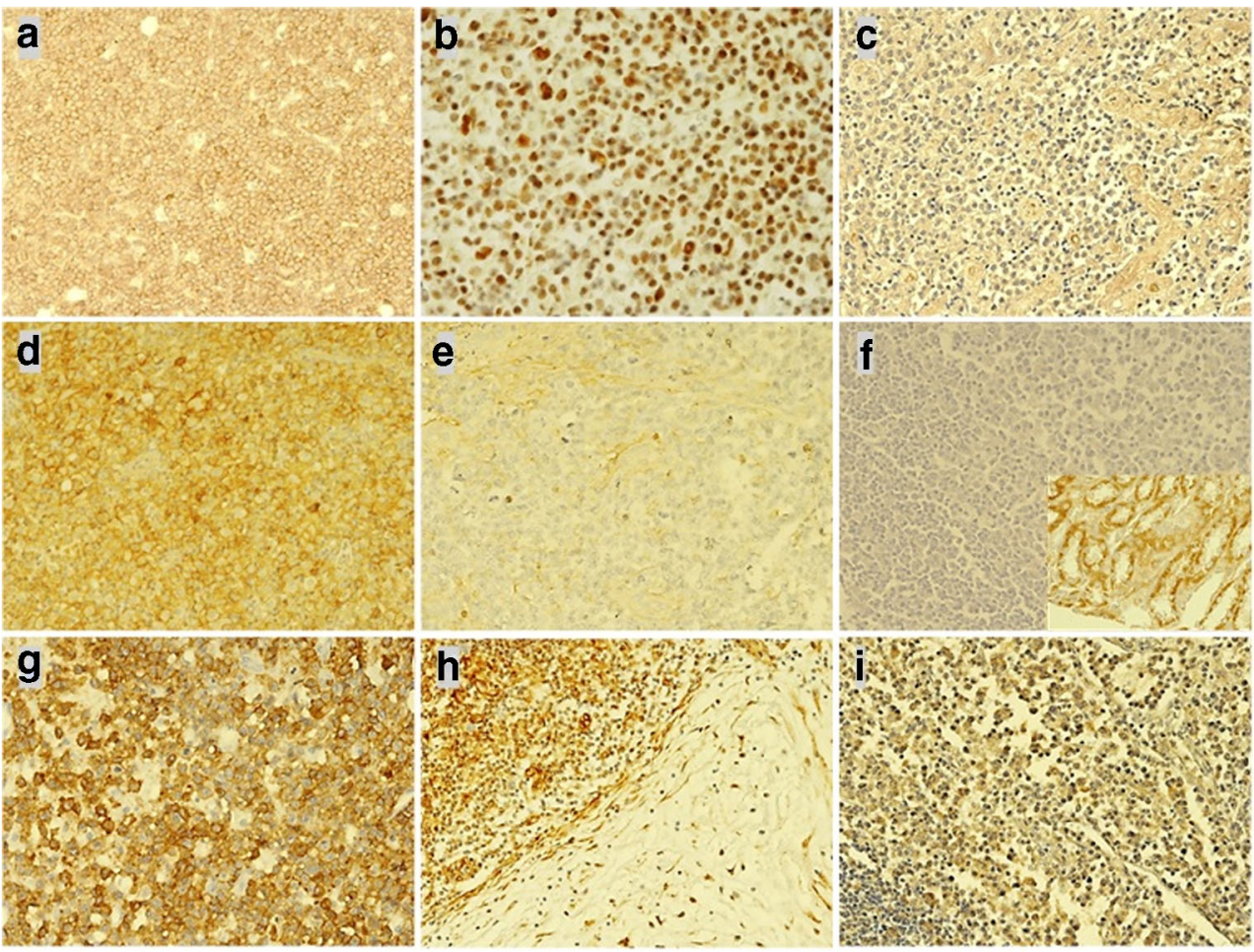

respectively). MCT1 expression was also found to be associated with low hemoglobin serum levels $(p=0.057)$. In addition, we found that MCT4 stromal expression was prevalent in high grade DLBCL cases $(p=0.015)$. Of the six cases that exhibited MCT1 nuclear expression in the tumour cells, five were graded stage III/ IV, four showed low hemoglobin levels, and none showed extranodal involvement (although the differences were not statistically significant due to the low number of positive cases).

Table 4 Immunoexpression and clinicopathological significance of biological parameters

\begin{tabular}{|c|c|c|c|c|}
\hline \multirow[t]{2}{*}{ Biomarker } & \multirow[t]{2}{*}{$\mathrm{n}$} & \multicolumn{2}{|l|}{ Positive immunoexpression (\%) } & \multirow{2}{*}{$\begin{array}{l}\text { Clinicopathological significance } * \\
\text { ( } p \text { values from } \chi^{2} \text { or Fisher's exact tests) }\end{array}$} \\
\hline & & Tumour compartment & Stromal compartment & \\
\hline \multirow[t]{2}{*}{ MCT1 } & \multirow[t]{2}{*}{103} & \multirow[t]{2}{*}{25 (24.3) [Positive nuclei in 6 (5.8) cases] } & \multirow[t]{2}{*}{ ND } & $\begin{array}{l}\text { Positive staining in the tumour compartment associated with high } \\
\text { grade }(18 \text { cases, } 72.0 \%, p=0.039) \text { and low hemoglobin serum } \\
\text { levels ( } 14 \text { cases, } 56.0 \%, p=0.057)\end{array}$ \\
\hline & & & & $\begin{array}{l}\text { Positive nuclear staining associated with stage III/IV } \\
\text { ( } 5 \text { cases, } 83.3 \%, p=\mathrm{ns}) \text {, low hemoglobin serum levels } \\
\text { ( } 4 \text { cases, } 66.7 \%, p=\mathrm{ns}) \text {, and non-occurrence } \\
\text { of extranodal involvement ( } 6 \text { cases, } 100 \%, p=\mathrm{ns})\end{array}$ \\
\hline MCT2 & 103 & $18(17.5)$ & $9(8.7)$ & - \\
\hline \multirow[t]{2}{*}{ MCT4 } & \multirow[t]{2}{*}{92} & \multirow[t]{2}{*}{$32(34.8)$} & \multirow[t]{2}{*}{$10(10.9)$} & $\begin{array}{l}\text { Positive staining in the tumour compartment associated with } \\
\text { high grade }(21 \text { cases, } 65.6 \%, p=0.051)\end{array}$ \\
\hline & & & & $\begin{array}{l}\text { Positive staining in the tumour stroma associated with high grade } \\
\quad(9 \text { cases, } 90.0 \%, p=0.015 \text { ) }\end{array}$ \\
\hline CD147 & 79 & ND & ND & - \\
\hline GLUT1 & 80 & $11(13.8)$ & ND & - \\
\hline LDHA & 90 & $5(5.6)$ & ND & - \\
\hline CAIX & 96 & $68(70.8)$ & $10(10.4)$ & $\begin{array}{l}\text { Positive staining in the tumour stroma associated with high } \\
\text { LDH serum levels ( } 6 \text { cases, } 60.0 \%, p=0.026 \text { ) and low } \\
\text { hemoglobin serum levels ( } 7 \text { cases, } 70.0 \%, p=0.039)\end{array}$ \\
\hline
\end{tabular}

*Clinicopathological parameters under statistical analysis include gender, age, pathological stage, grade, subtype of NHL, extra-nodal involvement, FLIPI (low grade tumours), IPI (high grade tumours), B symptoms, LDH serum levels, $\beta 2$-microglobulin serum levels, albumin serum levels, hemoglobin serum levels, ECOG performance status and first treatment results; $N D$ not detected, $n s$ not significant 
No associations were found when correlating the clinicopathological parameters with MCT2, GLUT1 and LDHA immunoexpression. Regarding CAIX expression, no associations were found when considering the tumour compartment, but stromal expression was found to be prevalent in cases with low hemoglobin $(p=0.039)$ and high LDHA serum levels $(p=0.026)$.

When analysing the prognostic significance of the biological parameters, none reached statistical significance in predicting progression-free or overall survival (PFS or OS). We did find, however, that MCT2 expression in high grade cases was associated with a more favourable prognostic profile (although not reaching statistical significance, the same tendency was observed regarding MCT1 and MCT4 expression) (Fig. 2).

\subsection{Multivariate analysis of significant prognostic variables}

Next, clinicopathological parameters that reached statistical significance in predicting a worse prognosis in NHL patients $(n=104)$ were subjected to multivariate analysis. By doing so, we found that pathological stage (HR 4.965, CI 1.901-12.966, $p=0.001$ ) and first treatment results (HR 2.289, CI $0.925-5.664, p=0.004)$ remained as independent prognostic factors for PFS $\left(\chi^{2}=67.617\right.$, $p<0.001$ ). In addition, we found that age (HR 3.446, CI 1.100-10.788), pathological stage (HR 3.442, 95\% CI $1.268-9.345, p=0.015)$, ECOG performance status (HR 3.714, 95\% CI 1.046-13.190, $p=0.042$ ) and first treatment results (HR 7.236, CI 2.503-20.923, $p<0.001$ ) remained as independent prognostic factors for OS $\left(\chi^{2}=\right.$ 48.177, $p<0.001)$. Multivariate analyses for low grade and high grade NHL patients (the last one including MCT2 membrane immunoexpression) were not informative (data not shown).

\subsection{Immunoexpression of biological parameters in lymphoma-derived cell lines}

Using immunofluorescence and Western blotting, we found that the DLBCL-derived cell lines $\mathrm{OZ}$ and DOHH-2 expressed MCT1 (Fig. 3a and c, respectively). The expression was predominantly membranous, particularly in $\mathrm{OZ}$ cells, and it co-localized with the chaperone CD147 (Fig. 3a). MCT4 expression was found to be weaker in both cell lines, and it co-localized with CD147 mainly in the cytoplasm (Fig. 3a and c). Both cell lines were found to express GLUT1, LDHA, CAIX and MCT2 in the cytoplasm. A membranous reinforcement was noted for GLUT1 (Fig. 3b and c).

\subsection{Effect of AZD1365 in lymphoma-derived cell lines}

Based on the above results on baseline levels of MCT in $\mathrm{OZ}$ and DOHH-2, it appears that these cells rely mainly on MCT1 for lactate transport across the plasma membrane. Therefore, we used AZD1365, a potent and selective inhibitor of MCT1 [34], to assess its effects on cell viability, apoptosis and lactate production. We found that the viability of both $\mathrm{OZ}$ and DOHH-2 cells was significantly compromised, although not completely inhibited, in a dose- and time-dependent manner, as shown in Fig. 4a (MTS assay) and 4b (Trypan blue exclusion assay). AZD1365 seemed to be particularly effective at $72 \mathrm{~h}$ post-treatment. This notion was corroborated by the analysis of extracellular lactate production: for both cell lines a significant reduction was found in lactate levels in the extracellular milieu, denoting efficient inhibition of lactate export (Fig. 4c). The OZ cells exhibited similar extracellular lactate levels after 10, 100 or $1000 \mathrm{nM}$ AZD3965 treatment. In case of DOHH-2 cells, 100 and 1000 nM AZD3965 were found to be significantly more effective than $10 \mathrm{nM}$ in inhibiting lactate production $(p<0.05)$. We found that apoptotic cell death was enhanced by AZD3965 treatment in a dose-dependent manner, indicated by increased levels of PARP [Poly (ADPribose) polymerase] cleavage, increased caspase 9 , Bax (Bcl2-associated X protein) and Bim (Bcl-2-like protein 11) expression (indicators of apoptosis induction), and decreased expression of Bcl-xL (B cell lymphoma-extra large; antiapoptotic protein) (Fig. 4d).

\section{Discussion}

In the present study, we aimed to evaluate the clinical and prognostic significance of a panel of glycolytic biomarkers in a comprehensive cohort of 104 NHL cases. We found that MCT1 and MCT4 were expressed in 24.3\% and 34.8\% of the tumour compartments of the tissue sections, respectively, and that they were associated with high grade and low hemoglobin serum levels, characteristic of an aggressive phenotype. Indeed, the vast majority of DLBCL samples was positive for MCT1 (72.0\%) and MCT4 (65.6\%), similar to what has been observed by Noble et al. [35] with respect to MCT1 expression (but not MCT4 expression, where positivity was only observed in $27 \%$ of DLBCL cases). Due to their correlation with tumour aggressiveness and poor outcome in various neoplastic disorders (reviewed in [36, 37]), these isoforms are best characterized. It has e.g. amply been reported that genetic and/or pharmacological inhibition of MCT1 and/or 4 in tumour cell lines and mice xenograft models of glioma [38], breast [39], colorectal [40], cervical [41] and lung [42] cancer leads to reduced lactate export, cell proliferation, migration and invasion, and increased responses to radiation and cell death. With respect to lymphomas, MCT4 has been found 
Fig. 2 Kaplan-Meier curves showing progression-free survival (a, c, e) and overall survival $(\mathbf{b}, \mathbf{d}, \mathbf{f})$ of patients with high grade non-Hodgkin lymphoma $(n=55)$, based on MCT1, MCT2 and MCT4 membrane expression status (tumour compartment)
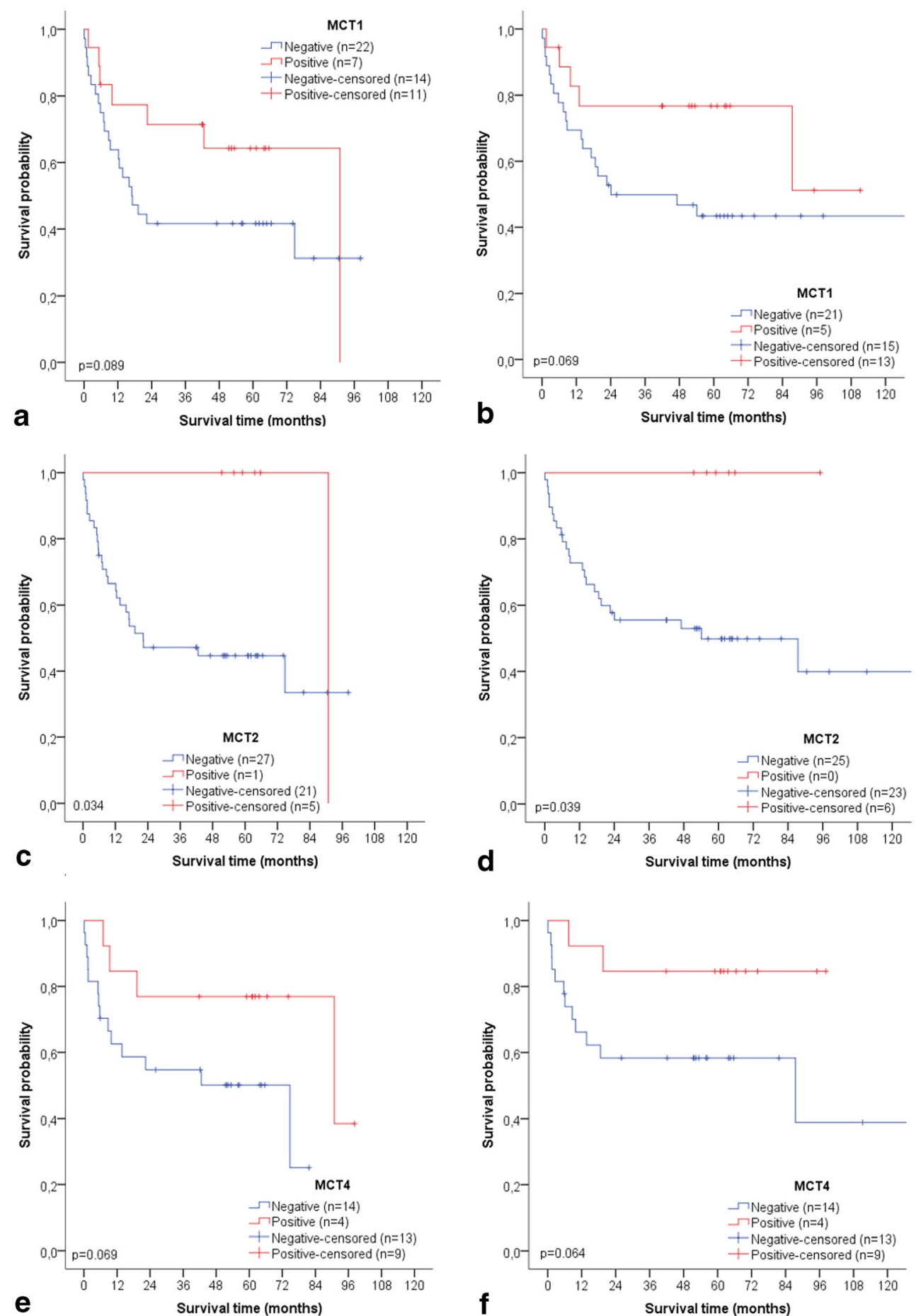

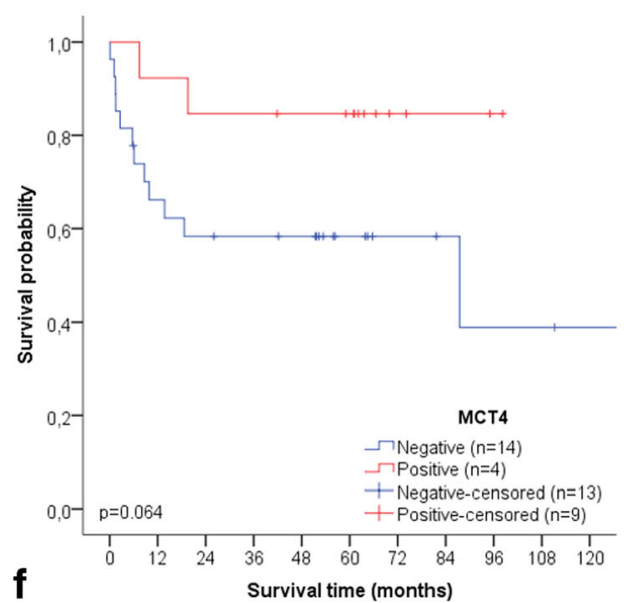

to be overexpressed in Burkitt's lymphomas and in lymphoblastoid cell lines [43]. Gan et al. found that expression of MCT1 was significantly elevated in $c-M Y C$ amplified lymphomas, correlating with a poor prognosis and an unfavourable survival. In the same study, MYC was found to sensitize cells, both in vitro and in vivo, to 3bromopyruvate, mediated by MCT1 overexpression [44]. It has been reported that MYC may regulate MCT1 expression (among other metabolic enzymes), and that elevated levels of this lactate transporter occur in human malignancies with MYC involvement [24, 44]. Recently, Broecker-Preuss et al. found that treatment with a MYC inhibitor decreased FDG uptake in three lymphoma-derived cell lines, thereby diminishing the expression of glycolysis-related genes and miRNAs [45].

An intriguing result of our study is the nuclear expression of MCT1, which was observed in six of the NHL cases and was associated with aggressiveness (the small sample size is a 
Fig. 3 Immunofluorescence (a and b) and Western blot (c) of baseline levels of MCT1 (a and c), MCT4 (a and c), CD147 (a and $\mathbf{c}$ ), GLUT1 (b and c), LDHA (b and $\mathbf{c}$ ), CAIX (b and $\mathbf{c}$ ) and MCT2 (b and c) in lymphomaderived $\mathrm{OZ}$ and DOHH-2 cell lines. In A co-localization of selected markers is shown. Cell nuclei were counterstained with DAPI, and pictures were obtained at 400x amplification using an Olympus ${ }^{\circledR}$ IX81 fluorescence microscope (a and $\mathbf{b})$. The Western blot data (c) are representative of similar blots from three independent passages
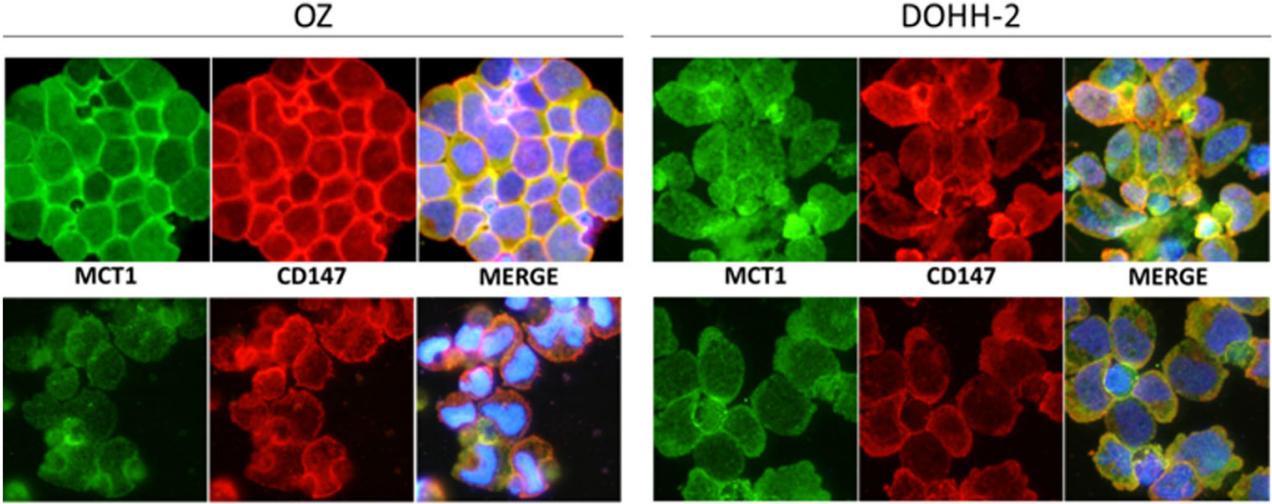

CD147

MERGE

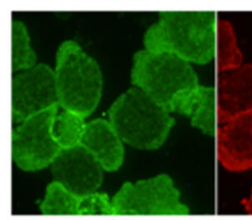

MCT4

MERGE

a

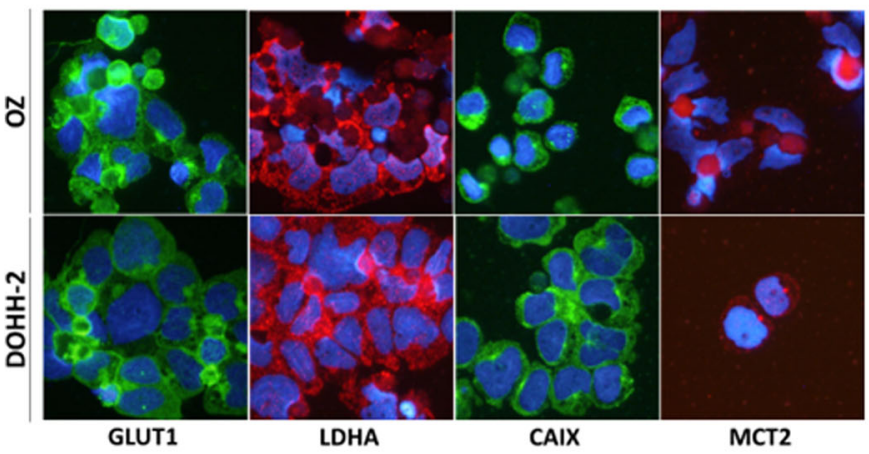

b

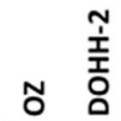

MCT1 (40-48 kDa)

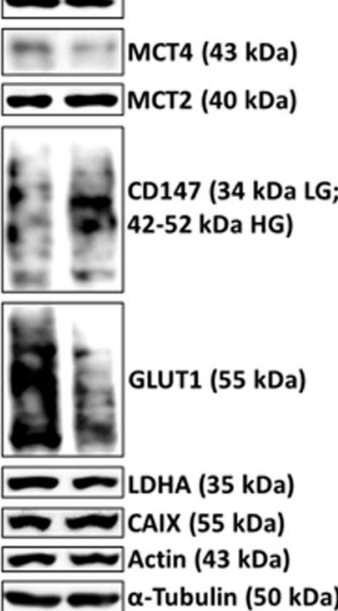

C

confirmed in a retrospective DLBCL cohort [48]. A similar phenotype has also been reported in Hodgkin lymphoma, with an elevated mitochondrial metabolism (high expression of MCT1) in the tumour cells and a glycolytic metabolism (high expression of MCT4) in tumour-associated macrophages [49]. This metabolic hijacking is exploited by several neoplasms for cell survival, progression, metastasis and chemotherapy resistance $[50,51]$. The molecular mechanisms underlying these interactions need to be further dissected, so that potential cancer associated stromal cell-based targets may be identified.

We found that MCT2 was expressed in $17,5 \%$ of the tumour sections, but no associations were found between MCT2 expression and clinical/follow-up data. In fact, the clinical and prognostic significance of MCT2 has so far only been described in prostate [52], brain [53], lung [54], pancreas [55] colorectal [56] and adrenocortical tumours [57]. An association between its cytoplasmic location and malignancy has been reported in prostate cancer [58]. Unexpectedly, when only high grade cases were considered in our analysis, 
Fig. 4 Effect of AZD3965 treatment $(10,100$ and $1000 \mathrm{nM}$ versus $0.01 \%$ DMSO) on the viability (a, MTS assay; b, Trypan blue exclusion assay), extracellular lactate production (c) and apoptotic death (d) of lymphoma-derived OZ and DOHH-2 cell lines. The MTS assay and Western blot $(\mathbf{d})$ analysis of proteins associated with cell death pathways (PARP, caspase 9,

Bcl-xL, Bim, Bax) were performed $72 \mathrm{~h}$ after treatment. The trypan blue exclusion assay (b) and quantification of extracellular lactate production (c) were performed $24 \mathrm{~h}, 48 \mathrm{~h}$ and $72 \mathrm{~h}$ post-treatment. $* p<0.05$, ** $p<0.01$, *** $p<0.001, * * * * p<0.0001$ AZD3965 versus control at each timepoint. Results of the cell viability (a and $\mathbf{b}$ ) and lactate production (c) assays are representative of three independent experiments, each one in triplicate. The Western blot data (d) are representative of similar blots from two independent experiments. CT, control (DMSO $0.01 \%) ; 10,100,1000, \mathrm{nM}$ AZD3965

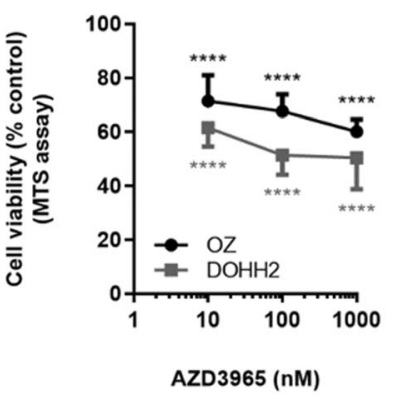

a

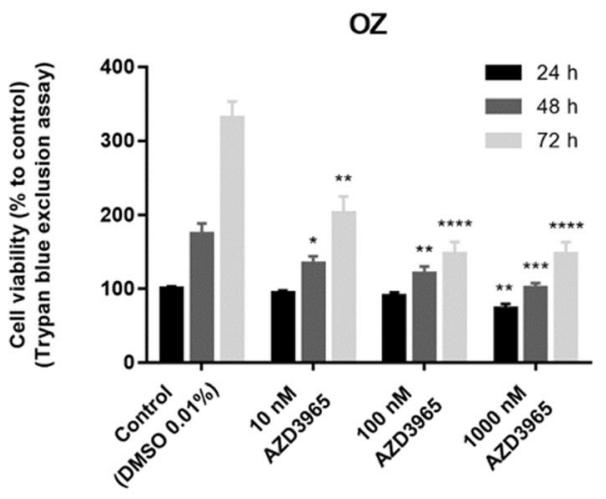

DOHH-2

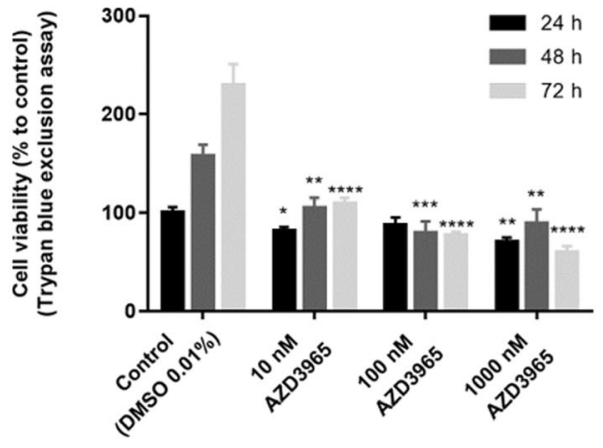

b

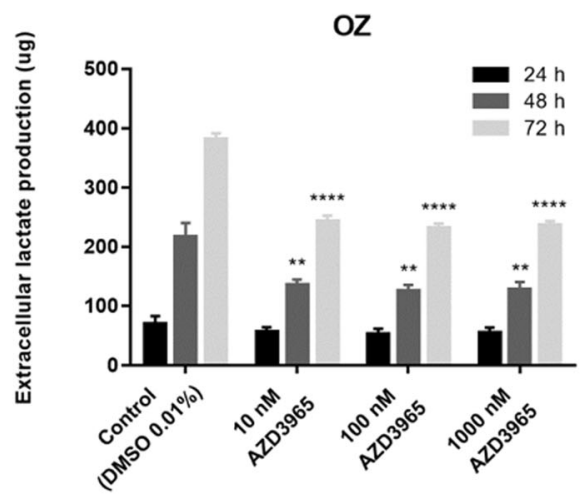

DOHH-2

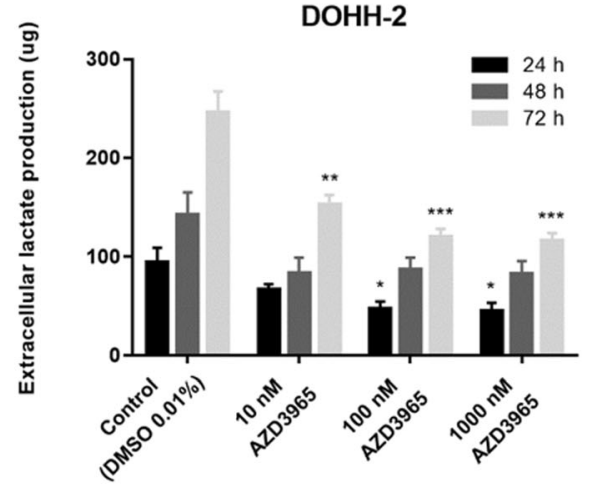

C

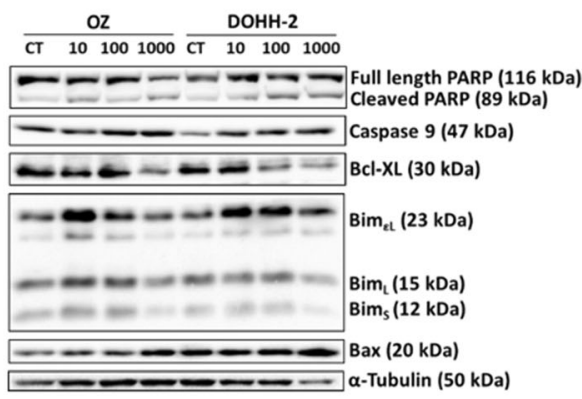

d
MCT2 expression was found to be significantly more prevalent in samples from patients with a longer progression-free and overall survival. The same tendency (although not significant) was observed when considering MCT1 and MCT4 expression. As noted before, Pinheiro et al. found a similar association regarding MCT1 nuclear expression in sarcomas [46]. To our knowledge, this is the first report describing an association of MCT plasma membrane expression with a favourable prognosis for cancer patients. DLBCL comprises a subset of NHL with a wide molecular and biological heterogeneity that contributes to clinical and prognostic disparities. Tumours displaying a high proliferative rate are more sensitive to chemotherapy and seem to present a metabolically active profile, as quantified by FDG-PET scanning [59, 60]. These tumours may overexpress MCT, which would be in accordance with our results. In different in vitro and in vivo cancer models, it has been shown that MCT activity may play an important role in tumour growth $[38,61]$. A closer look at the molecular level to this particular phenotype of MCT-expressing DLBCLs is warranted to further validate our results and to dissect this newly described profile of NHL patients.

MCTs interact with chaperone proteins to ensure expression and activity at the plasma membrane. While MCT2 preferentially associates with the immunoglobulin superfamily member gp70, MCT1 and MCT4 have been reported to interact with CD147 [62]. CD147 is a pleiotropic molecule with known associations to tumour aggressiveness and chemoresistance [63]. It has been reported that its pro- 
tumour action may closely be linked to MCT chaperoning activity [64]. In our study, CD147 expression was found to be absent in all cases, which is an intriguing observation that demands further study. It is possible that another co-carrier associates with MCT in NHL, namely CD44, which seems to contribute to the localization and function of MCT1 and MCT4 at the plasma membrane in several malignancies [33, $65,66]$. Hao et al., found that in vitro and in vivo prostate cancer metastasis and chemoresistance could be modulated by CD44 or CD147 expression, and that knock-down of either protein decreased MCT4 expression [67]. On the other hand, CD147 expression has been reported in haematological malignancies, both in pre-clinical and clinical settings, and its silencing has been found to inhibit tumour cell proliferation and to increase chemosensitivity [68, 69].

Our GLUT1 immunoexpression data indicate that $13.8 \%$ of the cases expressed this biomarker in the tumour compartment, but not in the stroma, which indicates that another isoform of the GLUT/SLC2 family may be responsible for glucose transport into fibroblasts. No associations with clinical and/or prognostic parameters were found. Watanabe et al. reported that 18F-FDG uptake may be associated with GLUT1 expression in primary gastric lymphomas [70]. Another study showed that both GLUT1 and GLUT 3 may contribute to $18 \mathrm{~F}-$ FDG uptake in an in vitro DLBCL model [71]. Conversely, and in accordance with our results, Shim et al. found that GLUT1 was not expressed in NHL tissues, and appeared to play no role in FDG uptake in NHL, whereas GLUT3 expression contributed significantly to FDG uptake [72].

$\mathrm{LDH}$, an enzyme that catalyses the conversion of pyruvate to lactate under hypoxia and/or as a result of oncogenic mutations, ensures an efficient glycolytic metabolism and a reduced dependency on oxygen [73]. Serum LDH is used as a biomarker for various neoplasms [74], including haematological malignancies $[75,76]$. Its increase may reflect an increase in tumour mass, tumour kinetics with a high mitotic index and a high rate of cell death. In our study, elevated LDH serum levels were found to be significantly associated with lower progression-free and overall survival rates. Expression of LDHA in the tissue sections was noted in $5.6 \%$ of the NHL cases, but did not reflect the same prognostic associations as serum LDH. However, $80 \%$ (4 out of 5) were high grade cases. In a study by $\mathrm{Lu}$ et al. [77] LDHA expression was scored positive in $85 \%$ of the tissue sections from 20 NHL patients, whereas benign controls were mainly scored negative. Malignant transformation may induce the expression of LDHA and its colocalization with HIF $1 \alpha$ in DLBCL cells, possibly reflecting an increase in lactate production and a release from tumour cells to the immunocompromised microenvironment. In another report, genetic or pharmacological inhibition of LDH expression in lymphoma cell lines and xenografts was found to cause bioenergetic and oxidative stress leading to cell death [20]. While the prognostic value of serum LDH for lymphoma patients is well documented, studies on LDH tissue expression are scarce and demand further investigation.

We also assessed the tissue distribution of the membranebound, extracellular acid trapper CAIX. Overexpression of this hypoxic marker is a frequent trait of malignancies, and has been correlated with tumour progression, invasion, metastasis and a poor prognosis [78]. In our series, $70.8 \%$ of the tumours expressed CAIX, although no associations with clinicopathological and/or prognostic parameters were noted. Similarly, Chen et al. observed heterogenous CAIX expression in a NHL cohort, probably reflecting differences in tumour microenvironments in different patients [79]. Intriguingly, in our series, $10.4 \%$ of the cases also expressed CAIX in the stromal compartment, being associated with a poor clinicopathological profile. This pattern has previously also been observed by our group in bladder cancer tissue sections [80], and may be a consequence of metabolic plasticity of the tumour microenvironment, where normoxic, hypoxic and "pseudo-hypoxic" populations may cohabit and cooperate.

Our results on the clinical significance of the glycolytic biomarkers, particularly MCT1, in DLBCL patients led us to further explore its biological role in vitro. We observed immunoexpression of the biomarkers in two DLBCLderived cell lines. The results pointed to MCT1-positive cells with a high dependence on the glycolytic pathway that efficiently exports lactate, mainly through MCT1. When treating the cells with AZD3965, a significant decrease in cell viability was observed, with a concomitant upregulation of proapoptotic proteins (and downregulation of an anti-apoptotic protein). Consistent with a role of MCT1 in lactate transport to the extracellular milieu, extracellular lactate levels were found to be significantly diminished upon treatment with the MCT1 inhibitor. A potent disruption of lactate transport and anti-tumour activity of AZD3965 were also demonstrated by others, in monotherapy and in combination, in aggressive NHL models both in vitro and in vivo [34, 35, 81]. The efficacy of AZD3965 is currently explored in a clinical trial encompassing adult solid tumour and DLBCL patients (NCT01791595), and exciting preliminary results have been obtained [82]. However, caution is recommended, as reports exist on the acquisition of resistance due to MCT4 compensatory lactate transport [24, 42, 83]. Public DLBCL gene expression data indicate that these tumours are among the lowest expressers of MCT4 mRNA [84], which would make them attractive targets for MCT1 inhibition. This notion has been confirmed in two studies on DLBCL cell lines [34, 35] and on a cohort of DLBCL patients [35]. The two cell lines that were used in our study also exhibited high MCT1 and low MCT4 expression levels, but in our cohort of DLBCL patients a similar and high percentage of positive cases for both biomarkers was noted. Additional studies are needed, both preclinical and clinical, to evaluate the efficacy AZD3965, either as 
monotherapy or in combination with classical or novel emerging anti-metabolic drug therapies, including patient stratification based on MCT expression status.

In summary, our findings indicate the occurrence of a glycolytic metabolism-dependent NHL phenotype that contributes to disease aggressiveness, and may harbour potential targets for therapeutic intervention, i.e., MCT1 targeting by AZD3965. Our results additionally point to the existence of a heterogeneous tumour microenvironment, where populations of oxidative cells (MCT1 expressers) coexist with glycolytic cells (MCT4 expressers). Each tumour compartment, with distinct metabolic demands, must cooperate with its cohabiting partners to achieve survival benefits. In this way, tumour progression, metastasis, immune escape and chemoresistance is reached. This phenotype, which is also apparent in other neoplasms, must be dissected in further detail, so that new approaches of targeted therapeutic intervention may be developed.

Acknowledgements This work was developed under the scope of project NORTE-01-0145-FEDER- 000013, supported by the Northern Portugal Regional Operational Programme (NORTE 2020) under the Portugal Partnership Agreement, through the European Regional Development Fund (FEDER), and through the Competitiveness Factors Operational Programme (COMPETE) and by National funds, through the Foundation for Science and Technology (FCT), under the scope of project POCI-01-0145-FEDER-007038. JA received a fellowship from FCT, ref. SFRH/BPD/116784/2016.

\section{Compliance with ethical standards}

Conflicts of interest The authors declare that they have no conflict of interest to disclose.

Research involving human participants All procedures performed in studies involving human participants were in accordance with the ethical standards of the institutional and/or national research committee and with the 1964 Helsinki declaration and its later amendments or comparable ethical standards. For this type of (retrospective) study formal consent is not required.

Publisher's note Springer Nature remains neutral with regard to jurisdictional claims in published maps and institutional affiliations.

\section{References}

1. J.O. Armitage, R.D. Gascoyne, M.A. Lunning, F. Cavalli, NonHodgkin lymphoma. Lancet 390, 298-310 (2017). https://doi.org/ 10.1016/S0140-6736(16)32407-2

2. B.C. Chiu, N. Hou, Epidemiology and etiology of non-hodgkin lymphoma. Cancer Treat Res 165, 1-25 (2015). https://doi.org/10. 1007/978-3-319-13150-4_1

3. J. Ferlay, I. Soerjomataram, R. Dikshit, S. Eser, C. Mathers, M. Rebelo, D.M. Parkin, D. Forman, F. Bray, Cancer incidence and mortality worldwide: Sources, methods and major patterns in GLOBOCAN 2012. Int J Cancer 136, E359-E386 (2015). https:// doi.org/10.1002/ijc. 29210
4. S.H. Swerdlow, E. Campo, S.A. Pileri, N.L. Harris, H. Stein, R. Siebert, R. Advani, M. Ghielmini, G.A. Salles, A.D. Zelenetz, E.S. Jaffe, The 2016 revision of the World Health Organization classification of lymphoid neoplasms. Blood 127, 2375-2390 (2016). https://doi.org/10.1182/blood-2016-01-643569

5. J.O. Armitage, Staging non-Hodgkin lymphoma. CA Cancer J Clin 55, 368-376 (2005)

6. B.D. Cheson, R.I. Fisher, S.F. Barrington, F. Cavalli, L.H. Schwartz, E. Zucca, T.A. Lister, Alliance, Australasian Leukaemia and Lymphoma Group, Eastern Cooperative Oncology Group, European Mantle Cell Lymphoma Consortium, Italian Lymphoma Foundation, European Organisation for Research, Treatment of Cancer/Dutch Hemato-Oncology Group, Grupo Español de Médula Ósea, German High-Grade Lymphoma Study Group, German Hodgkin's Study Group, Japanese Lymphoma Study Group, Lymphoma Study Association, NCIC Clinical Trials Group, Nordic Lymphoma Study Group, Southwest Oncology Group, United Kingdom National Cancer Research Institute, Recommendations for initial evaluation, staging, and response assessment of Hodgkin and non-Hodgkin lymphoma: The Lugano classification. J Clin Oncol 32, 3059-3068 (2014). https://doi.org/10.1200/JCO.2013.54.8800

7. A. Gallamini, C. Zwarthoed, A. Borra, Positron emission tomography (PET) in oncology. Cancers 6, 1821-1889 (2014). https://doi. org $/ 10.3390 /$ cancers 6041821

8. M.S. Hofman, R.J. Hicks, How we read oncologic FDG PET/CT. Cancer Imaging 16, 35 (2016). https://doi.org/10. 1186/s40644-016-0091-3

9. T.C. El-Galaly, M. Hutchings, Imaging of non-hodgkin lymphomas: Diagnosis and response-adapted strategies. Cancer Treat Res 165, 125146 (2015). https://doi.org/10.1007/978-3-319-13150-4 5

10. P. Johnson, H. McKenzie, How I treat advanced classical Hodgkin lymphoma. Blood 125, 1717-1723 (2015). https://doi.org/10.1182/ blood-2014-09-551556

11. I. Platzek, (18)F-Fluorodeoxyglucose PET/MR imaging in lymphoma. PET Clin 11, 363-373 (2016). https://doi.org/10.1016/j.cpet. 2016.05.001

12. C.L. Wright, J.J. Maly, J. Zhang, M.V. Knopp, Advancing precision nuclear medicine and molecular imaging for lymphoma. PET Clin 12, 63-82 (2017). https://doi.org/10.1016/j.cpet.2016.08.005

13. K. Miyazaki, Treatment of diffuse large B-cell lymphoma. J Clin Exp Hematop 56, 79-88 (2016). https://doi.org/10.3960/jslrt.56.79

14. D. Hanahan, R.A. Weinberg, Hallmarks of cancer: The next generation. Cell 144, 646-674 (2011). https://doi.org/10.1016/j.cell.2011.02.013

15. U.E. Martinez-Outschoorn, M. Peiris-Pages, R.G. Pestell, F. Sotgia, M.P. Lisanti, Cancer metabolism: A therapeutic perspective. Nat Rev Clin Oncol 14, 113 (2017). https://doi.org/10.1038/nrclinonc.2017.1

16. J.R. Doherty, J.L. Cleveland, Targeting lactate metabolism for cancer therapeutics. J Clin Invest 123, 3685-3692 (2013). https://doi. org/10.1172/JCI69741

17. U.E. Martinez-Outschoorn, M.P. Lisanti, F. Sotgia, Catabolic cancer-associated fibroblasts transfer energy and biomass to anabolic cancer cells, fueling tumor growth. Semin Cancer Biol 25, 47-60 (2014). https://doi.org/10.1016/j.semcancer.2014.01.005

18. G. van Niekerk, A.M. Engelbrecht, Role of PKM2 in directing the metabolic fate of glucose in cancer: A potential therapeutic target. Cell Oncol 41, 343-351 (2018). https://doi.org/10.1007/s13402018-0383-7

19. J.W. Kim, P. Gao, Y.C. Liu, G.L. Semenza, C.V. Dang, Hypoxiainducible factor 1 and dysregulated c-Myc cooperatively induce vascular endothelial growth factor and metabolic switches hexokinase 2 and pyruvate dehydrogenase kinase 1. Mol Cell Biol 27, 7381-7393 (2007). https://doi.org/10.1128/MCB.00440-07

20. A. Le, C.R. Cooper, A.M. Gouw, R. Dinavahi, A. Maitra, L.M. Deck, R.E. Royer, D.L. Vander Jagt, G.L. Semenza, C.V. Dang, Inhibition of lactate dehydrogenase a induces oxidative stress and 
inhibits tumor progression. Proc Natl Acad Sci U S A 107, 2037 2042 (2010). https://doi.org/10.1073/pnas.0914433107

21. A. Kumar, S. Kant, S.M. Singh, Novel molecular mechanisms of antitumor action of dichloroacetate against $\mathrm{T}$ cell lymphoma: Implication of altered glucose metabolism, $\mathrm{pH}$ homeostasis and cell survival regulation. Chem Biol Interact 199, 29-37 (2012). https:// doi.org/10.1016/j.cbi.2012.06.005

22. A. Kumar, S. Kant, S.M. Singh, Antitumor and chemosensitizing action of dichloroacetate implicates modulation of tumor microenvironment: A role of reorganized glucose metabolism, cell survival regulation and macrophage differentiation. Toxicol Appl Pharmacol 273, 196-208 (2013). https://doi.org/10.1016/j.taap.2013.09.005

23. N.G. Schaefer, J.F. Geschwind, J. Engles, J.W. Buchanan, R.L. Wahl, Systemic administration of 3-bromopyruvate in treating disseminated aggressive lymphoma. Transl Res 159, 51-57 (2012). https://doi.org/10.1016/j.trsl.2011.08.008

24. J.R. Doherty, C. Yang, K.E. Scott, M.D. Cameron, M. Fallahi, W. Li, M.A. Hall, A.L. Amelio, J.K. Mishra, F. Li, M. Tortosa, H.M. Genau, R.J. Rounbehler, Y. Lu, C.V. Dang, K.G. Kumar, A.A. Butler, T.D. Bannister, A.T. Hooper, K. Unsal-Kacmaz, W.R. Roush, J.L. Cleveland, Blocking lactate export by inhibiting the Myc target MCT1 disables glycolysis and glutathione synthesis. Cancer Res 74, 908-920 (2014). https://doi.org/10.1158/00085472.CAN-13-2034

25. S.H. Swerdlow, E. Campo, N.L.E. Harris, et al., WHO classification of Tumours of Haematopoietic and lymphoid tissues (IARC, Lyon, 2008)

26. T.A. Lister, D. Crowther, S.B. Sutcliffe, E. Glatstein, G.P. Canellos, R.C. Young, S.A. Rosenberg, C.A. Coltman, M. Tubiana, Report of a committee convened to discuss the evaluation and staging of patients with Hodgkin's disease: Cotswolds meeting. J Clin Oncol 7, 1630-1636 (1989). https://doi.org/10.1200/JCO.1989.7.11.1630

27. E. Hoster, A. Rosenwald, F. Berger, H.W. Bernd, S. Hartmann, C. Loddenkemper, T.F. Barth, N. Brousse, S. Pileri, G. Rymkiewicz, R. Kodet, S. Stilgenbauer, R. Forstpointner, C. Thieblemont, M. Hallek, B. Coiffier, U. Vehling-Kaiser, R. Bouabdallah, L. Kanz, M. Pfreundschuh, C. Schmidt, V. Ribrag, W. Hiddemann, M. Unterhalt, J.C. Kluin-Nelemans, O. Hermine, M.H. Dreyling, W. Klapper, Prognostic value of Ki-67 index, cytology, and growth pattern in mantle-cell lymphoma: Results from randomized trials of the European mantle cell lymphoma network. J Clin Oncol 34, 1386-1394 (2016). https://doi.org/10.1200/JCO.2015.63.8387

28. The international non-Hodgkin's lymphoma prognostic factors project, A predictive model for aggressive non-Hodgkin's lymphoma. N Engl J Med 329, 987-994 (1993). https://doi.org/10.1056/ NEJM199309303291402

29. P. Solal-Celigny, Follicular lymphoma international prognostic index. Curr Treat Options in Oncol 7, 270-275 (2006)

30. M.M. Oken, R.H. Creech, D.C. Tormey, J. Horton, T.E. Davis, E.T. McFadden, P.P. Carbone, Toxicity and response criteria of the eastern cooperative oncology group. Am J Clin Oncol 5, 649-655 (1982)

31. B.D. Cheson, S.J. Horning, B. Coiffier, M.A. Shipp, R.I. Fisher, J.M. Connors, T.A. Lister, J. Vose, A. Grillo-Lopez, A. Hagenbeek, F. Cabanillas, D. Klippensten, W. Hiddemann, R. Castellino, N.L. Harris, J.O. Armitage, W. Carter, R. Hoppe, G.P. Canellos, Report of an international workshop to standardize response criteria for non-Hodgkin's lymphomas. NCI Sponsored International Working Group. J Clin Oncol 17, 1244 (1999). https://doi.org/10. 1200/JCO.1999.17.4.1244

32. B.D. Cheson, B. Pfistner, M.E. Juweid, R.D. Gascoyne, L. Specht, S.J. Horning, B. Coiffier, R.I. Fisher, A. Hagenbeek, E. Zucca, S.T. Rosen, S. Stroobants, T.A. Lister, R.T. Hoppe, M. Dreyling, K. Tobinai, J.M. Vose, J.M. Connors, M. Federico, V. Diehl, L. International Harmonization, Project on, revised response criteria for malignant lymphoma. J Clin Oncol 25, 579-586 (2007). https:// doi.org/10.1200/JCO.2006.09.2403
33. C. Pinheiro, R.M. Reis, S. Ricardo, A. Longatto-Filho, F. Schmitt, F. Baltazar, Expression of monocarboxylate transporters 1, 2, and 4 in human tumours and their association with CD147 and CD44. J Biomed Biotechnol 2010, 427694 (2010). https://doi.org/10.1155/ 2010/427694

34. N.J. Curtis, L. Mooney, L. Hopcroft, F. Michopoulos, N. Whalley, H. Zhong, C. Murray, A. Logie, M. Revill, K.F. Byth, A.D. Benjamin, M.A. Firth, S. Green, P.D. Smith, S.E. Critchlow, Preclinical pharmacology of AZD3965, a selective inhibitor of MCT1: DLBCL, NHL and Burkitt's lymphoma anti-tumor activity. Oncotarget 8, 69219-69236 (2017). https://doi.org/10.18632/ oncotarget. 18215

35. R.A. Noble, N. Bell, H. Blair, A. Sikka, H. Thomas, N. Phillips, S. Nakjang, S. Miwa, R. Crossland, V. Rand, D. Televantou, A. Long, H.C. Keun, C.M. Bacon, S. Bomken, S.E. Critchlow, S.R. Wedge, Inhibition of monocarboxyate transporter 1 by AZD3965 as a novel therapeutic approach for diffuse large B-cell lymphoma and Burkitt lymphoma. Haematologica 102, 1247-1257 (2017). https://doi.org/ 10.3324/haematol.2016.163030

36. S. Granja, D. Tavares-Valente, O. Queiros, F. Baltazar, Value of $\mathrm{pH}$ regulators in the diagnosis, prognosis and treatment of cancer. Semin Cancer Biol 43, 17-34 (2017). https://doi.org/10.1016/j. semcancer.2016.12.003

37. R.S. Jones, M.E. Morris, Monocarboxylate transporters: Therapeutic targets and prognostic factors in disease. Clin Pharmacol Ther 100, 454-463 (2016). https://doi.org/10.1002/cpt.418

38. V. Miranda-Goncalves, M. Honavar, C. Pinheiro, O. Martinho, M.M. Pires, C. Pinheiro, M. Cordeiro, G. Bebiano, P. Costa, I. Palmeirim, R.M. Reis, F. Baltazar, Monocarboxylate transporters (MCTs) in gliomas: Expression and exploitation as therapeutic targets. Neuro-Oncology 15, 172-188 (2013). https://doi.org/10. 1093/neuonc/nos298

39. F. Morais-Santos, V. Miranda-Goncalves, S. Pinheiro, A.F. Vieira, J. Paredes, F.C. Schmitt, F. Baltazar, C. Pinheiro, Differential sensitivities to lactate transport inhibitors of breast cancer cell lines. Endocr Relat Cancer 21, 27-38 (2014). https://doi.org/10.1530/ ERC-13-0132

40. A. Kumar, S. Kant, S.M. Singh, Targeting monocarboxylate transporter by alpha-cyano-4-hydroxycinnamate modulates apoptosis and cisplatin resistance of Colo205 cells: Implication of altered cell survival regulation. Apoptosis 18, 1574-1585 (2013). https://doi. org/10.1007/s10495-013-0894-7

41. P. Sonveaux, F. Vegran, T. Schroeder, M.C. Wergin, J. Verrax, Z.N. Rabbani, C.J. De Saedeleer, K.M. Kennedy, C. Diepart, B.F. Jordan, M.J. Kelley, B. Gallez, M.L. Wahl, O. Feron, M.W. Dewhirst, Targeting lactate-fueled respiration selectively kills hypoxic tumor cells in mice. J Clin Invest 118, 3930-3942 (2008). https://doi.org/10.1172/JCI36843

42. R. Polanski, C.L. Hodgkinson, A. Fusi, D. Nonaka, L. Priest, P. Kelly, F. Trapani, P.W. Bishop, A. White, S.E. Critchlow, P.D. Smith, F. Blackhall, C. Dive, C.J. Morrow, Activity of the monocarboxylate transporter 1 inhibitor AZD3965 in small cell lung cancer. Clin Cancer Res 20, 926-937 (2014). https://doi.org/10. 1158/1078-0432.CCR-13-2270

43. M. Mushtaq, S. Darekar, G. Klein, E. Kashuba, Different mechanisms of regulation of the Warburg effect in Lymphoblastoid and Burkitt lymphoma cells. PLoS One 10, e0136142 (2015). https:// doi.org/10.1371/journal.pone. 0136142

44. L. Gan, R. Xiu, P. Ren, M. Yue, H. Su, G. Guo, D. Xiao, J. Yu, H. Jiang, H. Liu, G. Hu, G. Qing, Metabolic targeting of oncogene MYC by selective activation of the proton-coupled monocarboxylate family of transporters. Oncogene 35, 3037-3048 (2016). https:// doi.org/10.1038/onc. 2015.360

45. M. Broecker-Preuss, N. Becher-Boveleth, A. Bockisch, U. Duhrsen, S. Muller, Regulation of glucose uptake in lymphoma cell lines by c-MYC- and PI3K-dependent signaling pathways 
and impact of glycolytic pathways on cell viability. J Transl Med 15(158), 158 (2017). https://doi.org/10.1186/s12967-017-1258-9

46. C. Pinheiro, V. Penna, F. Morais-Santos, L.F. Abrahao-Machado, G. Ribeiro, E.C. Curcelli, M.V. Olivieri, S. Morini, I. Valenca, D. Ribeiro, F.C. Schmitt, R.M. Reis, F. Baltazar, Characterization of monocarboxylate transporters (MCTs) expression in soft tissue sarcomas: Distinct prognostic impact of MCT1 sub-cellular localization. J Transl Med 12, 118 (2014). https://doi.org/10.1186/1479-5876-12-118

47. U.E. Martinez-Outschoorn, D. Whitaker-Menezes, M. Valsecchi, M.P. Martinez-Cantarin, A. Dulau-Florea, J. Gong, A. Howell, N. Flomenberg, R.G. Pestell, J. Wagner, C. Arana-Yi, M. Sharma, F. Sotgia, M.P. Lisanti, Reverse Warburg effect in a patient with aggressive B-cell lymphoma: Is lactic acidosis a paraneoplastic syndrome? Semin Oncol 40, 403-418 (2013). https://doi.org/10.1053/ j.seminoncol.2013.04.016

48. M. Gooptu, D. Whitaker-Menezes, J. Sprandio, M. DomingoVidal, Z. Lin, G. Uppal, J. Gong, R. Fratamico, B. Leiby, A. Dulau-Florea, J. Caro, U. Martinez-Outschoorn, Mitochondrial and glycolytic metabolic compartmentalization in diffuse large Bcell lymphoma. Semin Oncol 44, 204-217 (2017). https://doi.org/ 10.1053/j.seminoncol.2017.10.002

49. L. Mikkilineni, D. Whitaker-Menezes, M. Domingo-Vidal, J. Sprandio, P. Avena, P. Cotzia, A. Dulau-Florea, J. Gong, G. Uppal, T. Zhan, B. Leiby, Z. Lin, B. Pro, F. Sotgia, M.P. Lisanti, U. Martinez-Outschoorn, Hodgkin lymphoma: A complex metabolic ecosystem with glycolytic reprogramming of the tumor microenvironment. Semin Oncol 44, 218-225 (2017). https://doi.org/ 10.1053/j.seminoncol.2017.10.003

50. M.I. Mitchell, A.M. Engelbrecht, Metabolic hijacking: A survival strategy cancer cells exploit? Crit Rev Oncol Hematol 109, 1-8 (2017). https://doi.org/10.1016/j.critrevonc.2016.11.010

51. P. Nilendu, S.C. Sarode, D. Jahagirdar, I. Tandon, S. Patil, G.S. Sarode, J.K. Pal, N.K. Sharma, Mutual concessions and compromises between stromal cells and cancer cells: Driving tumor development and drug resistance. Cell Oncol 41, 353-367 (2018). https://doi.org/10.1007/s13402-018-0388-2

52. N. Pertega-Gomes, J.R. Vizcaino, C. Gouveia, C. Jeronimo, R.M. Henrique, C. Lopes, F. Baltazar, Monocarboxylate transporter 2 (MCT2) as putative biomarker in prostate cancer. Prostate 73, 763-769 (2013). https://doi.org/10.1002/pros.22620

53. S.P. Mathupala, P. Parajuli, A.E. Sloan, Silencing of monocarboxylate transporters via small interfering ribonucleic acid inhibits glycolysis and induces cell death in malignant glioma: An in vitro study. Neurosurgery 55, 1410-1419; discussion 1419 (2004)

54. A. Giatromanolaki, E. Sivridis, S. Arelaki, M.I. Koukourakis, Expression of enzymes related to glucose metabolism in nonsmall cell lung cancer and prognosis. Exp Lung Res 43(1-8), 167-174 (2017). https://doi.org/10.1080/01902148.2017.1328714

55. D.E. Jung, J.M. Kim, C. Kim, S.Y. Song, Embigin is overexpressed in pancreatic ductal adenocarcinoma and regulates cell motility through epithelial to mesenchymal transition via the TGF-beta pathway. Mol Carcinog 55, 633-645 (2016). https://doi.org/10.1002/mc.22309

56. C. Pinheiro, A. Longatto-Filho, C. Scapulatempo, L. Ferreira, S. Martins, L. Pellerin, M. Rodrigues, V.A. Alves, F. Schmitt, F. Baltazar, Increased expression of monocarboxylate transporters 1, 2, and 4 in colorectal carcinomas. Virchows Arch 452, 139-146 (2008). https://doi.org/10.1007/s00428-007-0558-5

57. C. Pinheiro, S. Granja, A. Longatto-Filho, A.M. Faria, M.C. Fragoso, S.M. Lovisolo, A.M. Lerario, M.Q. Almeida, F. Baltazar, M.C. Zerbini, Metabolic reprogramming: A new relevant pathway in adult adrenocortical tumors. Oncotarget 6, 4440344421 (2015). https://doi.org/10.18632/oncotarget.5623

58. I. Valenca, N. Pertega-Gomes, J.R. Vizcaino, R.M. Henrique, C. Lopes, F. Baltazar, D. Ribeiro, Localization of MCT2 at peroxisomes is associated with malignant transformation in prostate cancer. J Cell Mol Med 19, 723-733 (2015). https://doi.org/10.1111/jcmm.12481
59. R. Karmali, L.I. Gordon, Molecular subtyping in diffuse large B cell lymphoma: Closer to an approach of precision therapy. Curr Treat Options in Oncol 18, 11 (2017). https://doi.org/10.1007/ s11864-017-0449-1

60. B. Kubuschok, G. Held, M. Pfreundschuh, Management of diffuse large B-cell lymphoma (DLBCL). Cancer Treat Res 165, 271-288 (2015). https://doi.org/10.1007/978-3-319-13150-4_11

61. F. Morais-Santos, S. Granja, V. Miranda-Goncalves, A.H. Moreira, S. Queiros, J.L. Vilaca, F.C. Schmitt, A. Longatto-Filho, J. Paredes, F. Baltazar, C. Pinheiro, Targeting lactate transport suppresses in vivo breast tumour growth. Oncotarget 6, 19177-19189 (2015). https://doi.org/10.18632/oncotarget.3910

62. A.P. Halestrap, The SLC16 gene family - structure, role and regulation in health and disease. Mol Asp Med 34, 337-349 (2013). https://doi.org/10.1016/j.mam.2012.05.003

63. X. Xin, X. Zeng, H. Gu, M. Li, H. Tan, Z. Jin, T. Hua, R. Shi, H. Wang, CD147/EMMPRIN overexpression and prognosis in cancer: A systematic review and meta-analysis. Sci Rep 6, 32804 (2016). https://doi.org/10.1038/srep32804

64. I. Marchiq, J. Albrengues, S. Granja, C. Gaggioli, J. Pouyssegur, M.P. Simon, Knock out of the BASIGIN/CD147 chaperone of lactate/H+ symporters disproves its pro-tumour action via extracellular matrix metalloproteases (MMPs) induction. Oncotarget 6, 2463624648 (2015). https://doi.org/10.18632/oncotarget.4323

65. M.G. Slomiany, G.D. Grass, A.D. Robertson, X.Y. Yang, B.L. Maria, C. Beeson, B.P. Toole, Hyaluronan, CD44, and emmprin regulate lactate efflux and membrane localization of monocarboxylate transporters in human breast carcinoma cells. Cancer Res 69, 1293-1301 (2009). https://doi.org/10.1158/0008-5472.CAN-08-2491

66. J. Afonso, L.L. Santos, V. Miranda-Goncalves, A. Morais, T. Amaro, A. Longatto-Filho, F. Baltazar, CD147 and MCT1potential partners in bladder cancer aggressiveness and cisplatin resistance. Mol Carcinog 54, 1451-1466 (2014). https://doi.org/ $10.1002 / \mathrm{mc} .22222$

67. J. Hao, M.C. Madigan, A. Khatri, C.A. Power, T.T. Hung, J. Beretov, L. Chang, W. Xiao, P.J. Cozzi, P.H. Graham, J.H. Kearsley, Y. Li, In vitro and in vivo prostate cancer metastasis and chemoresistance can be modulated by expression of either CD44 or CD147. PLoS One 7, e40716 (2012). https://doi.org/10. 1371/journal.pone.0040716

68. H. Gao, Q. Jiang, Y. Han, J. Peng, C. Wang, shRNA-mediated EMMPRIN silencing inhibits human leukemic monocyte lymphoma U937 cell proliferation and increases chemosensitivity to adriamycin. Cell Biochem Biophys 71, 827-835 (2015). https:// doi.org/10.1007/s12013-014-0270-4

69. J. Schmidt, I. Bonzheim, J. Steinhilber, I.A. Montes-Mojarro, C. Ortiz-Hidalgo, W. Klapper, F. Fend, L. Quintanilla-Martinez, EMMPRIN (CD147) is induced by C/EBPbeta and is differentially expressed in ALK+ and ALK- anaplastic large-cell lymphoma. Lab Invest 97, 1095-1102 (2017). https://doi.org/10.1038/labinvest. 2017.54

70. Y. Watanabe, H. Suefuji, Y. Hirose, H. Kaida, G. Suzuki, J. Uozumi, E. Ogo, M. Miura, K. Takasu, K. Miyazaki, K. Nakahara, M. Ishibashi, T. Okamura, K. Ohshima, N. Hayabuchi, 18F-FDG uptake in primary gastric malignant lymphoma correlates with glucose transporter 1 expression and histologic malignant potential. Int J Hematol 97, 43-49 (2013). https://doi.org/10.1007/s12185-012-1225-4

71. Y.M. Liu, X.M. Zhai, Y.W. Wu, Biological correlation between glucose transporters, Ki-67 and 2-deoxy-2-[18F]-fluoro-D-glucose uptake in diffuse large B-cell lymphoma and natural killer/T-cell lymphoma. Genet Mol Res 15 (2016). https://doi.org/10.4238/gmr.15027242

72. H.K. Shim, W.W. Lee, S.Y. Park, H. Kim, Y. So, S.E. Kim, Expressions of glucose transporter types 1 and 3 and hexokinaseII in diffuse large B-cell lymphoma and other B-cell non-Hodgkin's lymphomas. Nucl Med Biol 36, 191-197 (2009). https://doi.org/10. 1016/j.nucmedbio.2008.11.009 
73. V. Jurisic, S. Radenkovic, G. Konjevic, The actual role of LDH as tumor marker, Biochemical and Clinical Aspects. Adv Exp Med Biol 867, 115-124 (2015). https://doi.org/10.1007/978-94-017-7215-0_8

74. F. Petrelli, M. Cabiddu, A. Coinu, K. Borgonovo, M. Ghilardi, V. Lonati, S. Barni, Prognostic role of lactate dehydrogenase in solid tumors: A systematic review and metaanalysis of 76 studies. Acta Oncol 54, 961-970 (2015). https://doi.org/10.3109/0284186X.2015.1043026

75. W. Hu, X. Wang, R. Yang, Evaluation of D-dimer and lactate dehydrogenase plasma levels in patients with relapsed acute leukemia. Oncol Lett 12, 591-596 (2016). https://doi.org/10.3892/ol.2016.4657

76. B.M. William, N.R. Bongu, M. Bast, R.G. Bociek, P.J. Bierman, J.M. Vose, J.O. Armitage, The utility of lactate dehydrogenase in the follow up of patients with diffuse large B-cell lymphoma. Rev Bras Hematol Hemoter 35, 189-191 (2013). https://doi.org/10. 5581/1516-8484.20130055

77. R. Lu, M. Jiang, Z. Chen, X. Xu, H. Hu, X. Zhao, X. Gao, L. Guo, Lactate dehydrogenase 5 expression in non-Hodgkin lymphoma is associated with the induced hypoxia regulated protein and poor prognosis. PLoS One 8, e74853 (2013). https://doi.org/10.1371/journal.pone.0074853

78. S.J. van Kuijk, A. Yaromina, R. Houben, R. Niemans, P. Lambin, L.J. Dubois, Prognostic significance of carbonic anhydrase IX expression in Cancer patients: A meta-analysis. Front Oncol 6, 69 (2016). https://doi.org/10.3389/fonc.2016.00069

79. L.Q. Chen, C.M. Howison, C. Spier, A.T. Stopeck, S.W. Malm, M.D. Pagel, A.F. Baker, Assessment of carbonic anhydrase IX expression and extracellular $\mathrm{pH}$ in B-cell lymphoma cell line models. Leuk Lymphoma 56, 1432-1439 (2015). https://doi.org/10.3109/ 10428194.2014.933218

80. J. Afonso, L.L. Santos, A. Morais, T. Amaro, A. LongattoFilho, F. Baltazar, Metabolic coupling in urothelial bladder cancer compartments and its correlation to tumor aggressiveness. Cell Cycle 15, 368-380 (2016). https://doi. org/10.1080/15384101.2015.1121329

81. M. Beloueche-Babari, S. Wantuch, T. Casals Galobart, M. Koniordou, H.G. Parkes, V. Arunan, Y.L. Chung, T.R. Eykyn, P.D. Smith, M.O. Leach, MCT1 inhibitor AZD3965 increases mitochondrial metabolism, facilitating combination therapy and noninvasive magnetic resonance spectroscopy. Cancer Res 77, 59135924 (2017). https://doi.org/10.1158/0008-5472.CAN-16-2686

82. S.E.R. Halford, P. Jones, S. Wedge, S. Hirschberg, S. Katugampola, G. Veal, G. Payne, C. Bacon, S. Potter, M. Griffin, M. ChenardPoirier, G. Petrides, G. Holder, H.C. Keun, U. Banerji, E.R. Plummer, A first-in-human first-in-class (FIC) trial of the monocarboxylate transporter 1 (MCT1) inhibitor AZD3965 in patients with advanced solid tumours. J Clin Oncol 35, 2516-2516 (2017). https://doi.org/10.1200/JCO.2017.35.15_suppl.2516

83. R. Le Floch, J. Chiche, I. Marchiq, T. Naiken, K. Ilc, C.M. Murray, S.E. Critchlow, D. Roux, M.P. Simon, J. Pouyssegur, CD147 subunit of lactate/H+ symporters MCT1 and hypoxia-inducible MCT4 is critical for energetics and growth of glycolytic tumors. Proc Natl Acad Sci U S A 108, 16663-16668 (2011). https://doi.org/10.1073/pnas.1106123108

84. J. Barretina, G. Caponigro, N. Stransky, K. Venkatesan, A.A. Margolin, S. Kim, C.J. Wilson, J. Lehar, G.V. Kryukov, D. Sonkin, A. Reddy, M. Liu, L. Murray, M.F. Berger, J.E. Monahan, P. Morais, J. Meltzer, A. Korejwa, J. Jane-Valbuena, F.A. Mapa, J. Thibault, E. Bric-Furlong, P. Raman, A. Shipway, I.H. Engels, J. Cheng, G.K. Yu, J. Yu, P. Aspesi Jr., M. de Silva, K. Jagtap, M.D. Jones, L. Wang, C. Hatton, E. Palescandolo, S. Gupta, S. Mahan, C. Sougnez, R.C. Onofrio, T. Liefeld, L. MacConaill, W. Winckler, M. Reich, N. Li, J.P. Mesirov, S.B. Gabriel, G. Getz, K. Ardlie, V. Chan, V.E. Myer, B.L. Weber, J. Porter, M. Warmuth, P. Finan, J.L. Harris, M. Meyerson, T.R. Golub, M.P. Morrissey, W.R. Sellers, R. Schlegel, L.A. Garraway, The Cancer cell line encyclopedia enables predictive modelling of anticancer drug sensitivity. Nature 483, 603-607 (2012). https://doi.org/10.1038/nature11003 